\title{
FABRICATION AND LOADING OF LONG-TERM \\ STRESS CORROSION CRACKING SURVEILLANCE \\ SPECIMENS FOR THE DRESDEN 1 DECONTAMINATION PROGRAM
}

OCTOBER 1979

W. L. WALKER

GENERAL ELECTRIC COMPANY

NUCLEAR ENGINEERING DIVISION

175 CURTNER AVENUE

SAN JOSE, CA 95125

PREPARED FOR THE

U.S. DEPARTMENT OF ENERGY

DIVISION OF ENERGY TECHNOLOGY

UNDER CONTRACT EY-76-C-02-4014

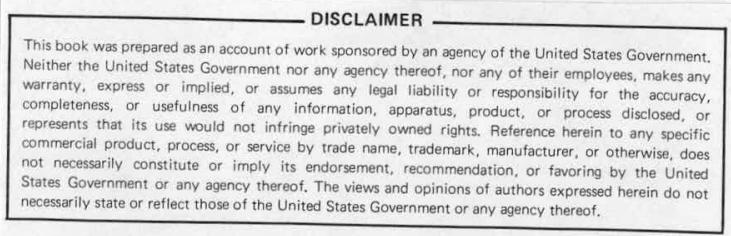




\section{DISCLAIMER}

This report was prepared as an account of work sponsored by an agency of the United States Government. Neither the United States Government nor any agency Thereof, nor any of their employees, makes any warranty, express or implied, or assumes any legal liability or responsibility for the accuracy, completeness, or usefulness of any information, apparatus, product, or process disclosed, or represents that its use would not infringe privately owned rights. Reference herein to any specific commercial product, process, or service by trade name, trademark, manufacturer, or otherwise does not necessarily constitute or imply its endorsement, recommendation, or favoring by the United States Government or any agency thereof. The views and opinions of authors expressed herein do not necessarily state or reflect those of the United States Government or any agency thereof. 


\section{DISCLAIMER}

Portions of this document may be illegible in electronic image products. Images are produced from the best available original document. 


\section{DISCLAIMER OF RESPONSIBILITY}

This document was prepared by the General Electric Company pursuant to a contract with the Commonwealth Edison Company. Except as otherwise provided in such contract, neither the General Electric Company nor any of the contributors to this document nor any of the sponsors of the work makes any warranty or representation (express or implied) with respect to the accuracy, completeness, or usefulness of the information contained in this document or that the use of such information may not infringe privately owned rights; nor do they assume any responsibility for liability or damage of any kind which may result from the use of any of the information contained in this document. 


\section{TABLE OF CONTENTS}

Page

ABSTRACT. ...vii

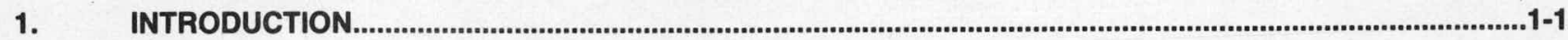

2. SUMMARY

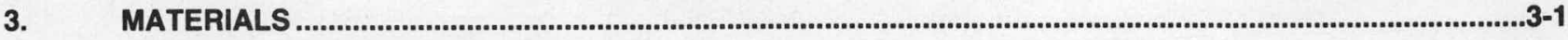

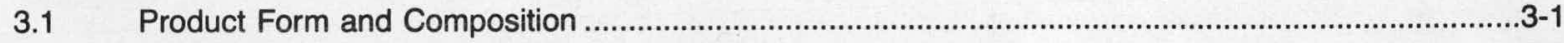

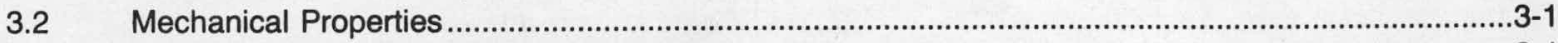

3.3 Materials Preparation and Heat-Treatment..............................................................................................

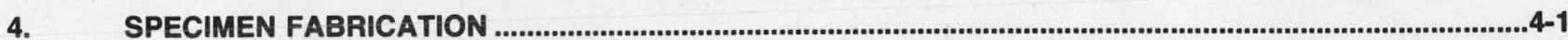

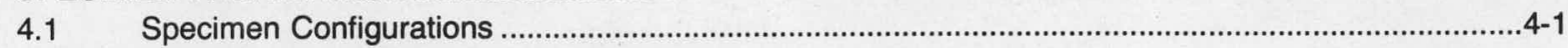

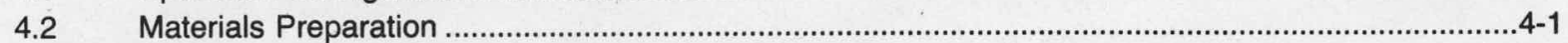

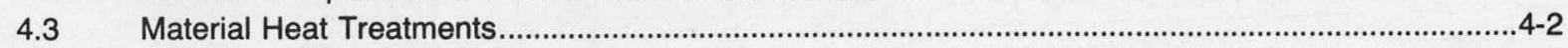

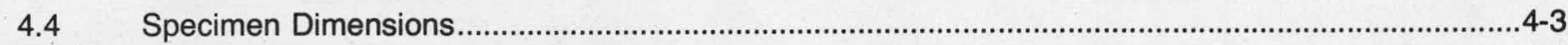

4.5 Number of Specimens Prepared ................................................................................................

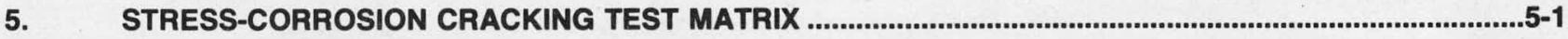

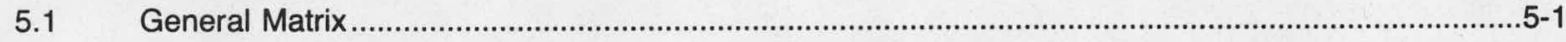

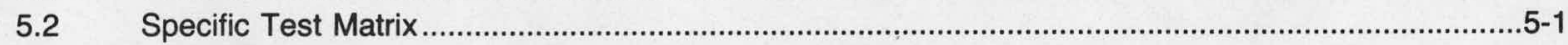

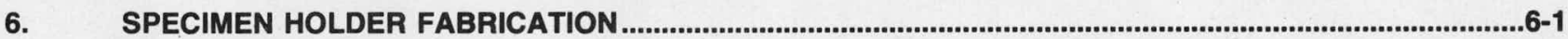

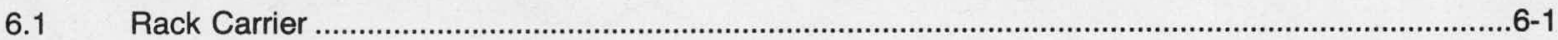

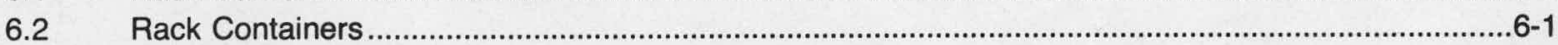

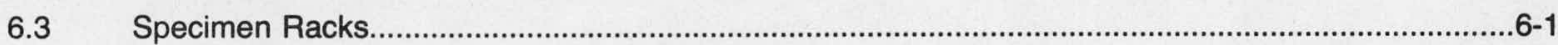

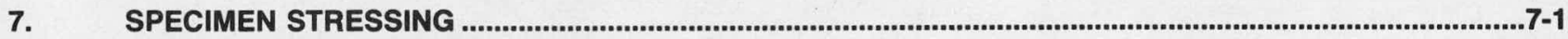

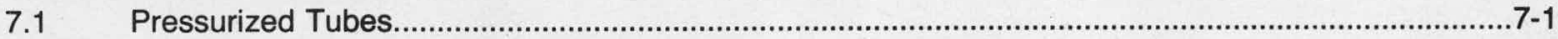

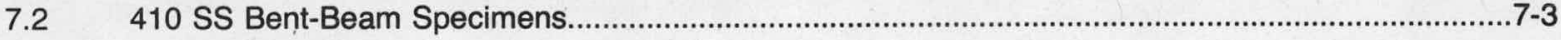

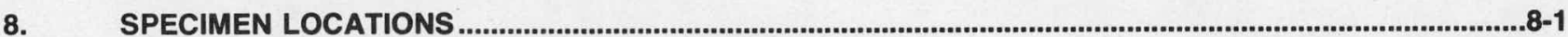

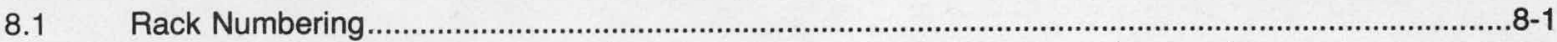

8.2 Specimen Numbering ..................................................................................................................... 8-1

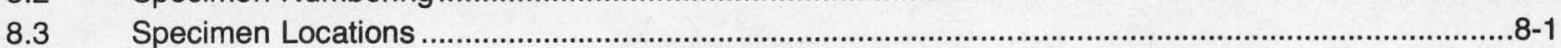

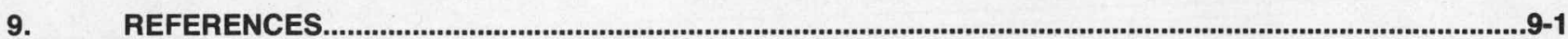

\section{APPENDICES}

A. MILL CERTIFICATIONS OF TEST MATERIALS

B. DETAILED SKETCHES OF INDIVIDUAL RACK CONTENTS ....................................................................

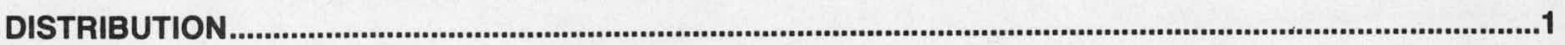




\section{LIST OF ILLUSTRATIONS}

Figure

Title

3-1 Sketch Showing Nominal Location of Capsule Bodies in As-Welded Test Materials

4-1 Pressurized Tube Specimen Sketch, and Detailed Drawings of Upper End Plug and Seal Plug

4-2 Type-410 SS Bent-Beam Specimen.

4-3 Constant Radius Block for Loading of the Type-410 SS Specimens.....

6-1 Dresden 1 Turning Vane Rack Carrier...

6-2 Pressurized Tube Rack Container

6-3 Dow In-Reactor Long-Term Surveillance Program Rack Container Identification Numbers 6-4

6-4 Pressurized Tube Specimen Rack

8-1 Sketches of Specimen Racks 3 and 18 Showing Specific

Specimen Sequences and Arrangements 8-4

\section{LIST OF TABLES}

Table

Title

Page

3-1 Product Form and Mill Certification Analysis of Materials in the Stress-Corrosion Cracking Surveillance Program.

3-2 Mechanical Properties of Surveillance Program Materials

4-1 Nominal Critical Capsule Body Dimensions of Pressurized Tube Specimens

5-1 Nominal Matrix for Long-Term Stress Corrosion Cracking Surveillance Program Specimens

7-1 Nominal Hoop Stresses and Fill Pressures of Pressurized Tube

Stress-Corrosion Cracking Surveillance Specimens.

7-2 "True" Stress on Pressurized Tube Specimens Using Mean

Measured Dimensional Values.

8-1 Stress-Corrosion Cracking Surveillance Program Specimen Rack Numbers.

8-2 Stress-Corrosion Cracking Surveillance Program Specimen Numbers. 


\begin{abstract}
Stress-corrosion cracking test specimens were prepared for Dow Nuclear Services for insertion in the Dresden 1 reactor during the chemical decontamination of the primary system, and for subsequent exposure under operating conditions when the station returns to service. The specimens consist of pressurized tubes fabricated from Type-304 and -304L stainless steel, Inconel 600, Incoloy 800, and Zircaloy 2. In addition, constant radius bent-beam specimens of $3 / 4$ hard Type- 410 stainless steel were also included. All specimens were stressed to, or slightly above, their respective $0.2 \%$ offset yield strengths at the temperatures of interest.
\end{abstract}




\section{INTRODUCTION}

A large laboratory corrosion test program has been conducted in association with the proposed chemical cleaning of the Dresden 1 nuclear power plant primary system, and the results of this work have been reported in several documents. ${ }^{1-4}$ None of the results obtained in the previous studies have indicated that the use of the proprietary Dow Chemical Company solvent (NS-1) developed for this cleaning operation would represent significant problems from a stress-corrosion cracking (SCC) standpoint either during the cleaning operation itself, or in subsequent service after completion of the cleaning. Although a large number of tests were performed by the Dow Chemical Company (Dow) and the General Electric Nuclear Technology Department (GE), these tests were limited in duration and were virtually all conducted under laboratory conditions. It was considered prudent to perform tests of longer duration, utilizing specimens which were exposed to NS-1 during the actual reactor cleaning operation itself and then exposed to the actual operating environment of the Dresden 1 plant in subsequent service. The information related to the fabrication and stressing of the SCC specimens in the program will be presented in this report. Dow has also inserted general corrosion rate specimens in the long-term surveillance program; however, the details of these specimens will be the subject of a Dow report.

The materials of primary concern included in this program were Type-304 stainless steel (304 SS), Type-304L stainless steel (304L SS), Inconel 600, and hardened Type-410 stainless steel (410 SS). Zircaloy 2 was included to evaluate the effects of NS-1 on that alloy for future reference purposes, since the Dresden 1 fuel will be removed from the vessel during the chemical cleaning operation. Incoloy 800 was included to provide information if the Dow NS-1 solvent is used on plants with that alloy present as heat exchanger tubing.

The specimens consist of pressurized tubes and constant radius bent beams in three general groups to evaluate the effects of the cleaning cycle NS-1 exposure only (one group) and the evaluation of the effects of the cleaning cycle plus subsequent service exposure (two groups: one exposed to NS-1 and a control group). The initial exposure of all specimens to NS-1 will be made in the Dresden 1 reactor pressure vessel (RPV) during the actual plant cleaning operation. If the "B" secondary steam generator test loop is available after the cleaning operation, half of the long-term surveillance specimens will be transferred to that location to permit relatively easy access for more frequent examinations and evaluations. If the loop should not be operative, all specimens will be exposed to subsequent service environment in the RPV turning vane location.

The specimens and holders were fabricated by GE, and the specimens were stressed by GE. The loaded specimens and holders were then shipped to Dow Nuclear Services, Midland, Michigan, for the addition of general corrosion rate specimens by Dow. The final set of specimens was inserted in the Dresden 1 RPV turning vane to await the primary system cleaning operation scheduled for early 1980 . This report documents the fabrication, treatment, stressing, and locations of the specimens prepared by GE. The future conduct of the long-term surveillance program is the responsibility of Dow Nuclear Services.

The work reported in this document was funded by the Commonwealth Edison Company and the U.S. Department of Energy (DOE), under DOE contract EY-76-C-02-4014A. 


\section{SUMMARY}

Pressurized tube specimens were fabricated from single heats of Type-304 and -304L SS, Inconel 600, Incoloy 800 , and Zircaloy 2. In addition, pressurized tubes were initially fabricated from $410 \mathrm{SS}$; however, the heat-treated strength of this alloy was such that the required pressure could not be obtained from the available equipment, and the handling of the specimens at the required pressure would have represented a significant safety hazard. For these reasons, the 410 SS specimens were exposed as fixed deflection constant radius bent beams. All long-term service specimens were stressed to the $288^{\circ} \mathrm{C}\left(550^{\circ} \mathrm{C}\right) 0.2 \%$ offset yield strength (YS), and specimens for evaluation of the cleaning cycle only were stressed to the ambient temperature $0.2 \%$ offset YS. Single heats of material were used for each alloy. The $0.2 \%$ offset $Y S$ was chosen as the test stress level, rather than a higher more conservative value, to assure that differences between the stress corrosion cracking behavior of the control and test specimens would be observable if they existed. At higher stresses, a significant fraction of the control specimens might fail during the first operating cycle and this would greatly reduce the sensitivity of the test to detect effects of the NS-1 exposure.

The 304 SS and 304L SS and the Inconel 600 specimens were exposed in two different conditions: severely sensitized by heat-treating at $620^{\circ} \mathrm{C}\left(1150^{\circ} \mathrm{F}\right)$ for 40 hours with a furnace cool, and in the as-welded condition. The Incoloy 800 specimens were exposed in the as-welded-condition; the Zircaloy- 2 specimens were exposed in the as-received condition, and the $410 \mathrm{SS}$ specimens were exposed in the $3 / 4$ hard condition. Three general groups of specimens were prepared: one to be removed after the NS-1 cleaning operation for destructive examination; one to be exposed to NS-1 during the cleaning operation and then to subsequent BWR service; and a third group which had seen no exposure to NS-1 and which acted as the control group for the subsequent service exposures. Multiple specimens of each alloy and condition were included in each group, with a nominal number of six in each set. The specimens were inserted in the Dresden 1 reactor vessel in December of 1978.

Details of the fabrication, heat-treatment, stressing, and loading of the long-term SCC surveillance specimens are presented in this report. 


\section{MATERIALS}

\subsection{PRODUCT FORM AND COMPOSITION}

The purchased product form and mill certification analysis for each alloy is shown in Table 3-1. Copies of mill certifications of test materials are presented in Appendix A. While the carbon content of the heat of $304 \mathrm{SS}$ is less than that typically encountered in BWR's, the heat was the most susceptible to IGSCC in the furnace sensitized condition of the seven heats characterized at the time of the start of the program; six of which had higher carbon contents than the chosen heat. ${ }^{5}$

Table 3-1

PRODUCT FORM AND MILL CERTIFICATION ANALYSIS OF MATERIALS IN THE STRESS-CORROSION CRACKING SURVEILLANCE PROGRAM

\begin{tabular}{|c|c|c|c|c|c|c|c|c|c|c|c|}
\hline Alloy & $\begin{array}{l}\text { Product } \\
\text { Form }\end{array}$ & C & Mn & $\mathbf{P}$ & $\mathbf{S}$ & Si & Mo & $\mathrm{Cr}$ & $\mathbf{N i}$ & $\mathrm{Cu}$ & Sn \\
\hline 304 SS & $\begin{array}{l}6 \text { in. } \\
\text { Schedule } 80 \\
\text { Pipe }\end{array}$ & $\begin{array}{l}0.045 \\
\text { (Balance }\end{array}$ & $\begin{array}{l}1.63 \\
\mathrm{Fe})\end{array}$ & 0.019 & 0.013 & 0.53 & - & 19.05 & 9.00 & - & - \\
\hline $304 \mathrm{~L}$ SS & $\begin{array}{l}3 / 4 \text { in. } \\
\text { Plate }\end{array}$ & $\begin{array}{l}0.028 \\
\text { (Balance }\end{array}$ & $\begin{array}{l}1.48 \\
\mathrm{Fe})\end{array}$ & 0.025 & 0.016 & 0.48 & 0.20 & 18.95 & 9.10 & 0.30 & - \\
\hline Inconel 600 & $\begin{array}{l}8 \text { in. o.d. } \\
5 \text { in. i.d. } \\
\text { Pipe }\end{array}$ & $\begin{array}{l}0.07 \\
\text { (Balance }\end{array}$ & $\begin{array}{l}0.17 \\
\mathrm{Fe})\end{array}$ & - & 0.007 & 0.23 & - & 15.33 & 75.61 & 0.19 & - \\
\hline Incoloy 800 & $\begin{array}{l}1 / 2 \text { in. } \\
\text { Plate }\end{array}$ & $\begin{array}{l}0.07 \\
(\mathrm{Al}-0 .\end{array}$ & $\begin{array}{c}0.89 \\
41, T i-\end{array}$ & $0 . \overline{43}$. B & $\begin{array}{l}0.002 \\
\text { lance } \mathrm{Fe} \text { ) }\end{array}$ & 0.43 & - & 20.33 & 32.55 & 0.55 & - \\
\hline $410 \mathrm{SS}$ & $\begin{array}{l}1 / 16 \text { in. } \\
\text { Sheet }\end{array}$ & $\begin{array}{l}0.14 \\
(\mathrm{Al}-0 . \mathrm{C}\end{array}$ & $\begin{array}{c}0.48 \\
025, N\end{array}$ & $\begin{array}{r}0.010 \\
-0.043,\end{array}$ & $\begin{array}{l}0.002 \\
\text { 3alance } F e\end{array}$ & $\begin{array}{l}0.40 \\
\text { e) }\end{array}$ & 0.06 & 11.89 & 0.20 & 0.05 & 0.001 \\
\hline $\mathrm{Zr}-2$ & $\begin{array}{l}1 / 2 \text { in. } \\
\text { Bar }\end{array}$ & $\begin{array}{l}0.011 \\
(A)-0 .\end{array}$ & $\begin{array}{c}0.002 \\
004, N\end{array}$ & $-\overline{-002}$ & -0.16 & $\begin{array}{l}0.007 \\
\text { Balanc }\end{array}$ & $\overline{\mathrm{Zr})}$ & 0.10 & 0.06 & 0.002 & 1.52 \\
\hline
\end{tabular}

\subsection{MECHANICAL PROPERTIES}

Room temperature mechanical properties were obtained from the mill certifications, except for the 410 SS which was tested in the heat-treated condition. Mechanical properties tests were performed on all materials at $288^{\circ} \mathrm{C}\left(550^{\circ} \mathrm{F}\right)$ in the as-received condition, except for the $410 \mathrm{SS}$ which was tested in the heat-treated condition. The results are shown in Table 3-2.

\subsection{MATERIALS PREPARATION AND HEAT-TREATMENT}

The materials represented in this program were tested in a variety of conditions. The $304 \mathrm{SS}, 304 \mathrm{~L} \mathrm{SS}$, and Inconel 600 alloys were tested in both the as-welded condition and the severely sensitized condition. The severely sensitized condition is representative of material which would be subjected to a post-weld heat-treatment with the RPV, and consisted of a heat-treatment of 40 hours at $620^{\circ} \mathrm{C}\left(1250^{\circ} \mathrm{F}\right)$ followed by a slow furnace cool. The Incoloy 800 material was tested in the as-welded condition only. The Zircaloy 2 was tested in the as-received condition, and the 410 SS was tested in the $3 / 4$ hard condition. 
Table 3-2

MECHANICAL PROPERTIES OF SURVEILLANCE PROGRAM MATERIALS

\section{Room Temperature}

\begin{tabular}{|c|c|c|c|c|c|}
\hline Alloy & Heat No. & $0.2 \%$ YS & UTS $^{a}$ & $\% E^{a}$ & $\% \mathbf{R A}^{a}$ \\
\hline 304 SS & 78500 & $235 \mathrm{mPa}$ (34.1 ksi) & $549 \mathrm{mPa}$ (79.6 ksi) & 75 & - \\
\hline 304L SS & V58077 & $236 \mathrm{mPa}(34.3 \mathrm{ksi})$ & $581 \mathrm{mPa}(84.2 \mathrm{ksi})$ & 60 & - \\
\hline Inconel 600 & NX2715 & $241 \mathrm{mPa}$ (35.0 ksi) & $607 \mathrm{mPa}(88.0 \mathrm{ksi})$ & 43 & 56 \\
\hline Incoloy 800 & $\mathrm{HH} 7077 \mathrm{~A}$ & $238 \mathrm{mPa}$ (34.5 ksi) & $607 \mathrm{mPa}(88.0 \mathrm{ksi})$ & 44 & 61 \\
\hline $410 \mathrm{SS}^{b}$ & 8644145 & $931 \mathrm{mPa}(135 \mathrm{ksi})$ & $1055 \mathrm{mPa}$ (153 ksi) & 7 & 59 \\
\hline $\mathrm{Zr}-2$ & $397208 Q$ & $375 \mathrm{mPa}$ (54.0 ksi) & $555 \mathrm{mPa}$ (80.6 ksi) & 24 & - \\
\hline \multicolumn{6}{|c|}{$288^{\circ} \mathrm{C}\left(550^{\circ} \mathrm{F}\right)$} \\
\hline 304 L SS & 78500 & $136 \mathrm{mPa}(19.7 \mathrm{ksi})$ & $426 \mathrm{mPa}(61.8 \mathrm{ksi})$ & 51 & 75 \\
\hline 304 L SS & V58077 & $142 \mathrm{mPa}(20.6 \mathrm{ksi})$ & $439 \mathrm{mPa}(63.7 \mathrm{ksi})$ & 44 & 67 \\
\hline Inconel 600 & NX2715 & $181 \mathrm{mPa}(26.3 \mathrm{ksi})$ & $590 \mathrm{mPa}(85.5 \mathrm{ksi})$ & 44 & 56 \\
\hline Incoloy 800 & HH7077A & $145 \mathrm{mPa}(21.1 \mathrm{ksi})$ & $481 \mathrm{mPa}(69.8 \mathrm{ksi})$ & 40 & 58 \\
\hline $410 \mathrm{SS}^{b}$ & 8644145 & $820 \mathrm{mPa}(119 \mathrm{ksi})$ & $917 \mathrm{mPa}$ (133 ksi) & 4 & 55 \\
\hline $\mathrm{Zr}-2$ & $397208 Q$ & $155 \mathrm{mPa}(22.5 \mathrm{ksi})$ & $271 \mathrm{mPa}$ (39.3 ksi) & 26 & 68 \\
\hline
\end{tabular}

The fabrication of the test specimens, with the exception of those of $410 \mathrm{SS}$, involved welding to produce the pressurized tube configuration. However, the welds involve only simple fusion of thin-wall sections and do not represent the structural welds of interest, except in the case of Zircaloy 2 fuel cladding. To reproduce a reasonable facsimile of a structural weld, full thickness welds were made in the other materials, except for the Inconel 600, in their as-received thicknesses; the tubular test sections of the specimens (to be described in the next section) were machined from these welds with the centerline of the weld in the approximate center of the tubular specimen. Material thicknesses were such that both the root and crown sides of the original weld were reasonably represented on the finished specimens, as shown in Figure 3-1.

Originally, tubular specimens were prepared from 410 SS and heat treated in accordance with current General Electric Nuclear Technology Department specifications. However, a subsequent check of the heat-treatment used for this alloy in the construction of the Dresden 1 plant revealed that a significantly harder material condition was used. It was not possible to pressurize the tubes to the required stress level with existing equipment and, had it been possible, the handling of thin-walled tubes under those pressures would have represented a significant safety hazard. For these reasons, fixed deflection bent beams were chosen as the test specimen configuration for the $410 \mathrm{SS}$. The primary purpose of the pressurized tube specimen is to compensate for stress relaxation at service temperature in materials such as the austenitic stainless steels. Since no significant relaxation would be anticipated in the hardened $410 \mathrm{SS}$, the use of the bent-beam configuration was considered acceptable.

a UTS = Ultimate Tensile Strength

$E=$ Elongation

RA $=$ Reduction in Area

b Heat treated $1 \mathrm{hr}$ at $982^{\circ} \mathrm{C}\left(1800^{\circ} \mathrm{F}\right)$ and oil quenched, then tempered for $1 \mathrm{hr}$ at $566^{\circ} \mathrm{C}\left(1050^{\circ} \mathrm{F}\right)$ and air cooled. 


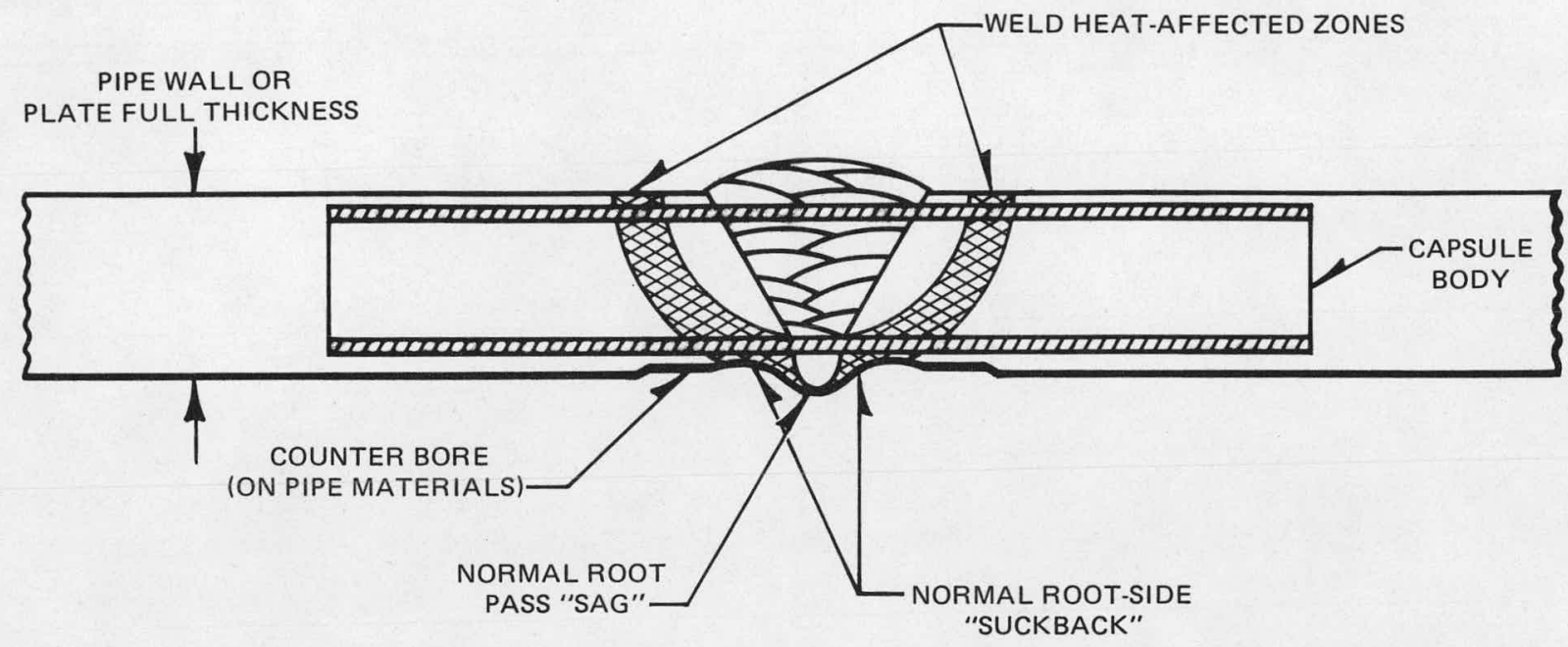

Figure 3-1. Sketch Showing Nominal Location of Capsule Bodies in As-Welded Test Materials 


\section{SPECIMEN FABRICATION}

\subsection{SPECIMEN CONFIGURATIONS}

The pressurized tube specimen is shown in Figure 4-1. The capsule body was fabricated from the heat of material being tested and the end seal plugs were fabricated from the same alloy, but not necessarily the same heat of material. Internal mandrels were used in all specimens to reduce the kinetic energy released in the event of a tube rupture, and all mandrels were fabricated from $304 \mathrm{SS}$. The capsule bodies were welded to the end plugs by single pass fusion welds using the tungsten-inert gas process. All welding was performed in an inert gas-filled chamber.

The bent beam specimen used for the $410 \mathrm{SS}$ is shown in Figure 4-2, and the constant radius block used for stressing the specimens is shown in Figure 4-3. The radius blocks were fabricated from 304 SS, and 304 SS Allen screws were used for mounting the specimens.

\subsection{MATERIALS PREPARATION}

\subsubsection{SS}

A standard 30-degree bevel, extended land, weld preparation was made on the pipe for consumable insert welding. The welding procedure used duplicated a conventional pipe field weld, with an inert gas-tungsten arc root fusion pass of the consumable insert, a single layer of inert gas-tungsten arc weld with filler metal, and completion of the weld with the shielded metal arc process. Filler metal for all layers was 308 SS. Longitudinal sections were cut through the completed weld for fabrication into capsule bodies, with the centerline of the weld in the approximate center of the final machined capsule body.

The non-welded specimens were prepared from longitudinal sections cut from the as-received pipe.

\subsubsection{L SS}

The configuration of the $304 \mathrm{~L}$ SS material (plate) prohibited duplicating a pipe weld. However, the weld preparation was identical and a length of 308 SS welding rod was used to simulate a consumable insert. Welding processes and parameters were as nearly identical to those used on the 304 SS pipe weld as was practical, and the edges of the plates were tacked to a strongback to prevent serious bowing of the plate and to provide restraint comparable to that which would be encountered in a pipe weld. Weld filler metal used was $308 \mathrm{SS}$. The rolling direction of the plate was perpendicular to the welding direction to provide a final specimen orientation identical to that of the $304 \mathrm{SS}$. Longitudinal sections were cut through the completed weld for fabrication into capsule bodies, with the centerline of the weld in the approximate center of the final machined capsule body.

The non-welded specimens were prepared from sections cut parallel to the rolling direction of the plate.

\subsubsection{Inconel 600}

The heavy-walled Inconel 600 pipe was machined on both the inside diameter (i.d.) and the outside diameter (o.d.) to produce a wall thickness equivalent to that of a 6 in. Schedule 80 pipe (approximately $0.432 \mathrm{in}$.) and was then prepared for welding in the same manner as the 304 SS pipe. An inert gas-tungsten arc root fusion pass was made with a consumable insert, and a second layer was deposited by inert gas-tungsten arc weld with filler metal. The remainder of the weld was completed using the shielded metal arc process. Weld filler metal used was Inconel 82 and 182. Longitudinal sections were cut through the completed weld for fabrication into capsule bodies with the weld centerline in the approximate center of the final machined capsule body.

The non-welded specimens were prepared from longitudinal sections cut from the machined pipe. 


\subsubsection{Incoloy 800}

The preparation of the welded Incoloy 800 specimens was identical to that of the $304 \mathrm{~L} \mathrm{SS} \mathrm{specimens.} \mathrm{A} \mathrm{consumable}$ insert weld prep was machined on the plate edges and the welding procedure duplicated that of a pipe weld insofar as was practical. The rolling direction of the plate was perpendicular to the direction of welding, and the plate was restrained during the welding process. Weld filler metal used was Inconel 82 and 182. Longitudinal sections were cut through the completed weld for fabrication into capsule bodies with the centerline of the weld in the approximate center of the final machined capsule body. Incoloy 800 was tested in the as-welded condition only.

\subsubsection{SS}

As stated previously, the original intent was to test $410 \mathrm{SS}$ as pressurized tubes but the pressures required to achieve the desired stress level were prohibitive, both from an equipment and a personnel safety standpoint. The original material purchased was discarded and 16-gage sheet material was ordered. Bent-beam specimens were machined from the sheet stock oriented parallel to the rolling direction. The 410 SS was tested in the heat-treated condition only.

\subsubsection{Zircaloy 2}

Zircaloy 2 was tested in the as-received condition on the main portion of the capsule body. The areas immediately adjacent to the end plug closure welds can be considered to represent the as-welded condition because the wall thickness is similar to that of fuel cladding. However, the stresses will be lower than those calculated for the main capsule body. Capsule bodies were simply machined from the $1 / 2$ in. diameter round bar in the as-received condition.

\subsection{MATERIAL HEAT TREATMENTS}

\subsubsection{SS, 304L SS, Inconel 600}

The two austenitic stainless steels and the nickel-base austenitic alloy were tested in two conditions: as-welded and severely sensitized. The sensitizing heat-treatment simulated that which a component attached to the RPV might be expected to experience during post-weld heat-treatment of the vessel and consisted of 40 hours at $620^{\circ} \mathrm{C}\left(1150^{\circ} \mathrm{F}\right)$ followed by a furnace cool. This heat-treatment was performed in an inert gas atmosphere after the completion of all specimen fabrication operations.

\subsection{2 $410 \mathrm{SS}$}

It was considered desirable to test the $410 \mathrm{SS}$ in the same heat-treat condition as that present in the Dresden 1 plant. However, a search of the available records did not provide definitive information as to the actual condition of that alloy.

Conversations with two GE engineers who were involved with materials and fabrication of the Dresden 1 vessel indicated that the material was used in the " $3 / 4 \mathrm{Hard"} \mathrm{condition} \mathrm{and} \mathrm{that} \mathrm{the} \mathrm{hardness} \mathrm{in} \mathrm{the} \mathrm{heat-treated} \mathrm{condition} \mathrm{was} \mathrm{"in}$ the middle Rockwell C30's." A series of tests indicated that these two criteria were met by a heat-treatment consisting of austenitizing at $982^{\circ} \mathrm{C}\left(1800^{\circ} \mathrm{F}\right)$ for 1 hour with an oil quench, followed by tempering at $566^{\circ} \mathrm{C}\left(1050^{\circ} \mathrm{F}\right)$ for 1 hour with an air $\mathrm{cool}$. These heat-treatments were performed in an inert gas atmosphere and the material exhibited $0.2 \% \mathrm{YS}$ and UTS of 931 $\mathrm{mPa}(135 \mathrm{ksi})$ and $1055 \mathrm{mPa}$ (153 ksi), respectively, and a hardness of Rockwell C34.

\subsubsection{Incoloy 800 and Zircaloy-2}

As stated previously, no specific heat-treatments were performed upon specimens fabricated from either of these alloys. 


\subsection{SPECIMEN DIMENSIONS}

Two groups of specimens were fabricated: one for exposure during the cleaning cycle only at $121^{\circ} \mathrm{C}\left(250^{\circ} \mathrm{F}\right)$, and the other for exposure to the cleaning cycle and then to the operating plant environment at $288^{\circ} \mathrm{C}\left(550^{\circ} \mathrm{F}\right)$. Because of limits on the capability of the pressurizing equipment, and the difference in expansion of the fill gas at the two temperatures, the wall thickness of the capsule body of specimens for the cleaning cycle set was thinner than that of specimens intended for subsequent service exposure. In addition, weld shrinkage effects and weld deposit irregularities on the welded $304 \mathrm{SS}$ and Inconel 600 materials required that a somewhat smaller capsule body be used to assure that all specimens could be machined from the welded pipes. The nominal critical capsule body dimensions (i.d. and wall thickness) for each group of specimens are shown in Table 4-1.

Since the dimensions of the bent-beam specimens fabricated from 410 SS were independent of temperature, pressure, and intended exposure, all specimens from this alloy were identical. The dimensions of these specimens are shown in Figure 4-2; the dimensions of the constant radius loading block are shown in Figure 4-3.

Finished dimensional variance of the capsule bodies was checked by measuring the finished bodies of 20 specimens, representing 5 specimens each from the as-received and as-welded $304 \mathrm{SS}$ and Inconel 600 sets. The mean wall thickness for the 20 capsule bodies was 0.0455 in., with a mean standard deviation of 0.0003 in. The mean i.d. of the as-welded capsule bodies was 0.2807 in., and the mean i.d. of the as-received capsule bodies was $0.3111 \mathrm{in}$. Since all of the specimens were machined in the same shop, and the four sets from which the samples were taken were machined at different points in time, the results indicated excellent consistency on the part of the fabricator.

\subsection{NUMBER OF SPECIMENS PREPARED}

The test matrix, described in Section 6 , required 30 specimens for each material/condition combination tested. A total of 35 specimens were prepared for each material/condition to provide spares in the event that faulty tubes were encountered during the pressurizing operation. Only 30 bent-beam specimens were prepared from the $410 \mathrm{SS}$ because no defects would be encountered in such specimens. 
Table 4-1

NOMINAL CRITICAL CAPSULE BODY DIMENSIONS OF PRESSURIZED TUBE SPECIMENS

\section{Material}

304 SS

304 SS

304 SS

304 SS

304L SS

304L SS

304L SS

304L SS

Inconel 600

Inconel 600

Inconel 600

Inconel 600

Incoloy 800

Incoloy 800

Zircaloy 2

Zircaloy 2
Condition

As-Welded

Sensitized

As-Welded

Sensitized

As-Welded

Sensitized

As-Welded

Sensitized

As-Welded

Sensitized

As-Welded

Sensitized

As-Welded

As-Welded

As-Received

As-Received

\section{Nominal Dimensions}

\section{Specimen}

Group

Cleaning Cycle
Cleaning Cycle
BWR Service
BWR Service

Cleaning Cycle

Cleaning Cycle

BWR Service

BWR Service

Cleaning Cycle

Cleaning Cycle

BWR Service

BWR Service

Cleaning Cycle

BWR Service

Cleaning Cycle

BWR Service

\section{Capsule Body}

i.d. (in.)

0.280
0.312
0.280
0.312

0.312

0.312

0.312

0.312

0.312

0.280

0.312

0.280

0.312

0.312

0.312

0.312

0.312
Capsule Body Wall Thickness (in.)
0.025
0.025
0.044
0.044

0.025

0.025

0.044

0.044

0.025

0.025

0.044

0.044

0.025

0.044

0.025

0.044 


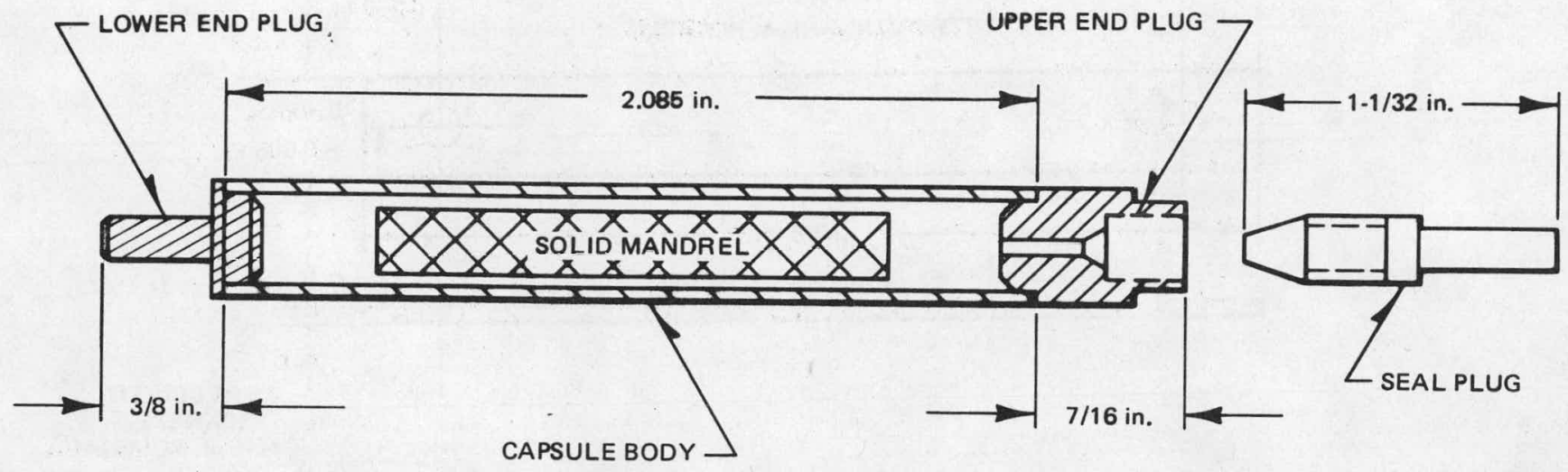

PRESSURIZED TUBE SPECIMEN

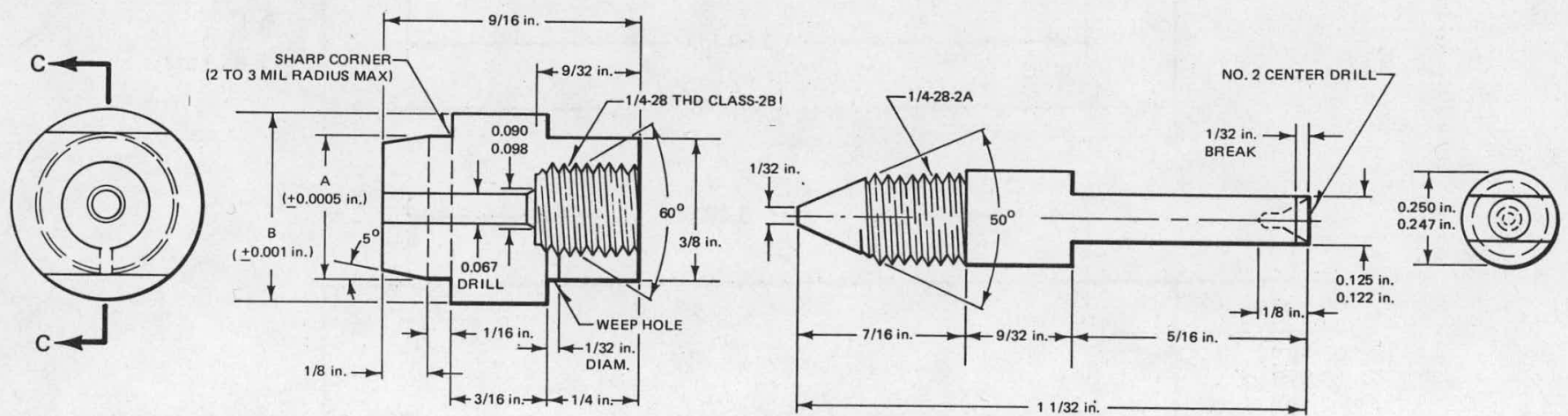

ALL DIMENSIONS IN INCHES

NOTE: THREADS AND CONE

SEAT MUST BE MADE

DURING SAME CHUCKING

OPERATION TO INSURE

PERFECT CONCENTRICITY.

UPPER END PLUG DETAIL
NOTE: THREADS AND CONE

TIP MUST BE MADE

DURING SAME CHUCKING

OPERATION TO INSURE

PERFECT CONCENTRICITY.

SEAL PLUG DETAIL

Figure 4-1. Pressurized Tube Specimen Sketch, and Detailed Drawings of Upper End Plug and Seal Plug 


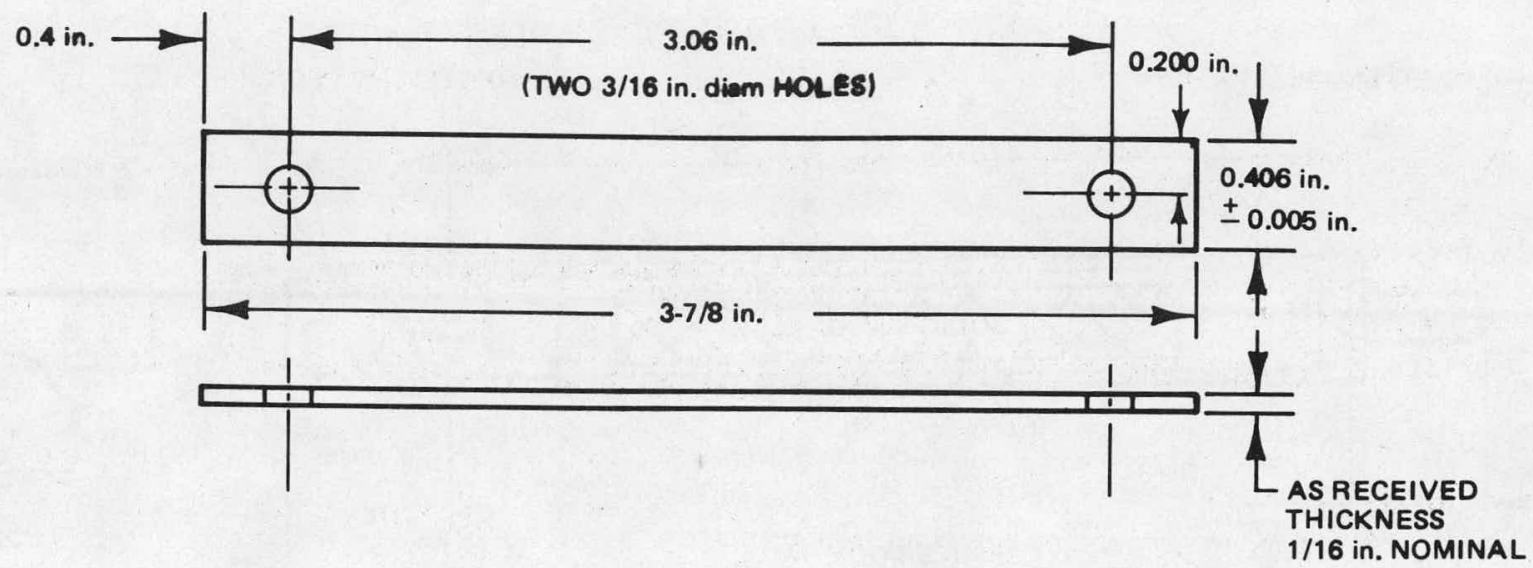

Figure 4-2. Type-410 SS Bent-Beam Specimen
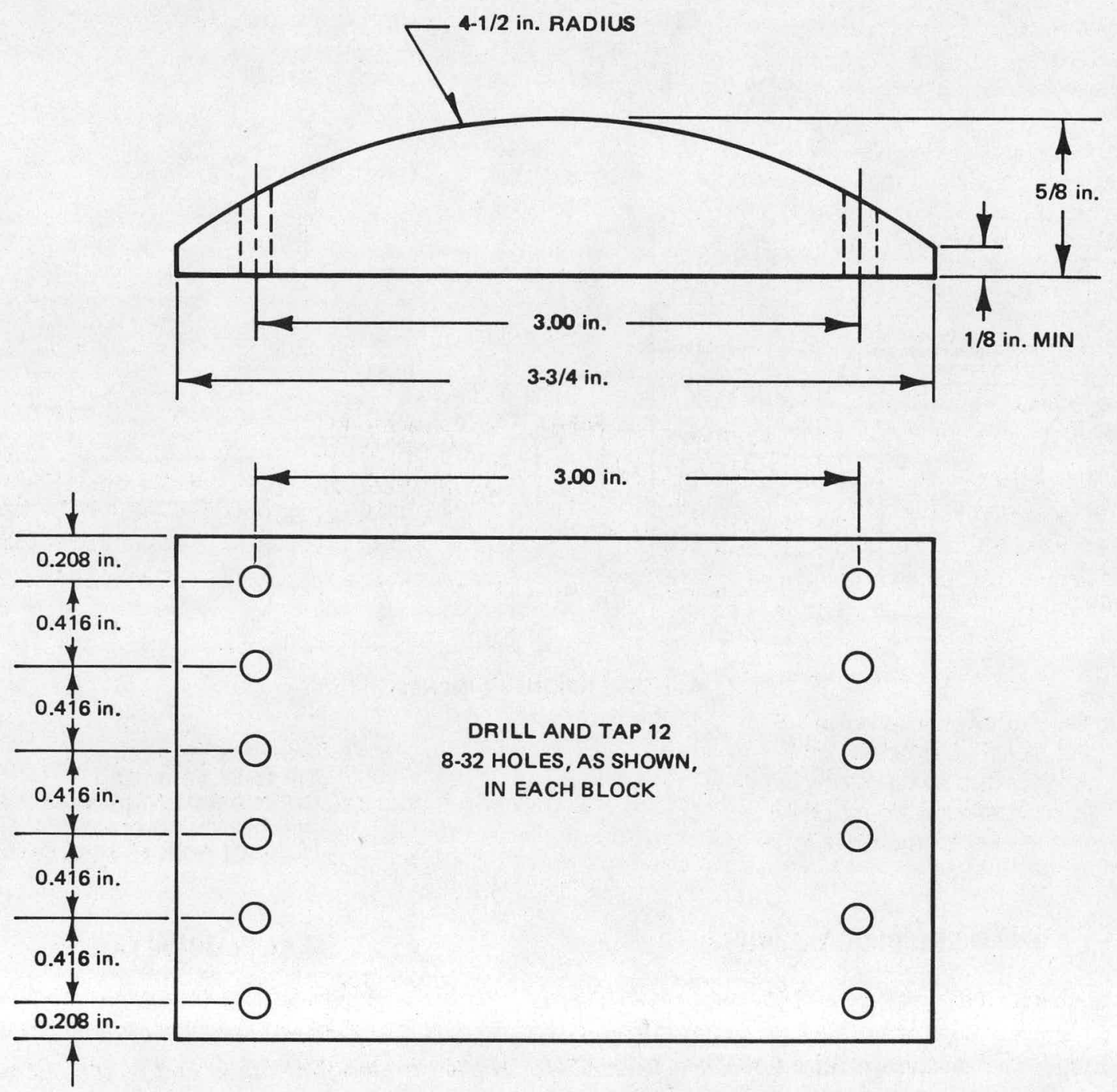

Figure 4-3. Constant Radius Block for Loading of the Type-410 SS Specimens 


\section{STRESS-CORROSION CRACKING TEST MATRIX}

\subsection{GENERAL MATRIX}

The general matrix consists of five groups of specimens described as (1) Cleaning Cycle, (2) RPV Control, (3) RPV Cleaning, (4) B-Loop Control, and (5) B-Loop Cleaning. The specific definitions of these groups are as follows.

\subsubsection{Cleaning Cycle Specimens}

These specimens were stressed to the ambient temperature $0.2 \%$ offset $Y S$ of the individual heats of material tested. The specimens will be exposed during the actual plant cleaning operation and then removed for examination. Examinations performed may include destructive metallography. None of these specimens will be returned to the reactor for subsequent exposure to the operating environment when the plant returns to service.

\subsubsection{RPV Control Specimens}

These specimens will act as controls and will not be inserted in the RPV until after the completion of the chemical cleaning, and will see no exposure to the cleaning solvent. The pressurized tube specimens were filled to a pressure which would result in a nominal stress of the $288^{\circ} \mathrm{C}\left(550^{\circ} \mathrm{F}\right) 0.2 \%$ offset $\mathrm{YS}$ of the individual heats of material at the operating temperature of the plant when it returns to service. The $410 \mathrm{SS}$ bent-beam specimens were stressed over constant radius blocks to give a strain equal to that of the $288^{\circ} \mathrm{C}\left(550^{\circ} \mathrm{F}\right) 0.2 \%$ YS.

\subsubsection{RPV Cleaning Specimens}

These specimens will be exposed to the cleaning solvent during the actual plant cleaning operation, and will then be returned to the RPV turning vane for subsequent service exposure to the normal operating environment. Like the RPV Controls, these specimens were pressurized such that they would be stressed to the $288^{\circ} \mathrm{C}\left(550^{\circ} \mathrm{F}\right) 0.2 \%$ offset $Y S$ during normal plant operation. This means that during the actual cleaning operation these specimens will be stressed to approximately two-thirds of that value, because of the lower temperature of the cleaning solution, i.e., $121^{\circ} \mathrm{C}\left(250^{\circ} \mathrm{F}\right)$.

\subsubsection{B-Loop Control Specimens}

These specimens are identical to the RPV Controls, but will be exposed to subsequent plant operation in the B secondary steam generator test loop if that facility is operative following the cleaning operation. Should the facility not be operative, these specimens will be exposed in the RPV turning vane with the RPV Controls. The purpose of both groups of B-loop specimens is to provide for more frequent examinations of the surveillance specimens than would be provided by the normal plant refueling outages, without interruption of plant operation.

\subsubsection{B-Loop Cleaning Specimens}

These specimens are identical to the RPV Cleaning specimens, and will be exposed to the actual plant cleaning cycle in the RPV and then will be transferred to the B secondary steam generator test loop, if that facility is operative, for subsequent plant operational exposure. The purpose is to provide for more frequent examinations without interruption of normal plant operation. Should the B-loop facility not be available, these specimens will be exposed to subsequent plant operation in the RPV turning vane area along with the RPV Cleaning specimens.

\subsection{SPECIFIC TEST MATRIX}

The specific test matrix for the SCC is shown in Table 5-1. Each material/condition combination is represented in each of the five groups as a set of six (nominally) specimens. In a few instances, less than six specimens are present because of original material fabrication weld defects which did not permit repair and repressurization of the specimens. The total number of specimens represented by the nominal test matrix is 270 . 
Table 5-1

NOMINAL MÀTRIX FOR LONG-TERM STRESS-CORROSION

CRACKING SURVEILLANCE PROGRAM SPECIMENS

\begin{tabular}{|c|c|c|c|c|c|}
\hline Alloy/Condition & $\begin{array}{c}\text { Cleaning } \\
\text { Cycle }\end{array}$ & $\begin{array}{c}\text { RPV } \\
\text { Control }\end{array}$ & $\begin{array}{c}\text { RPV } \\
\text { Cleaning }\end{array}$ & $\begin{array}{l}\text { B-Loop } \\
\text { Control }\end{array}$ & $\begin{array}{l}\text { B-Loop } \\
\text { Cleaning }\end{array}$ \\
\hline \multicolumn{6}{|l|}{304 SS } \\
\hline As-Welded & $x$ & $x$ & $x$ & $x$ & $x$ \\
\hline Sensitized $^{a}$ & $x$ & $x$ & $x$ & $x$ & $x$ \\
\hline \multicolumn{6}{|l|}{ 304L SS } \\
\hline As-Welded & $x$ & $x$ & $x$ & $x$ & $x$ \\
\hline Sensitized ${ }^{a}$ & $x$ & $x$ & $x$ & $x$ & $x$ \\
\hline \multicolumn{6}{|l|}{ Inconel 600} \\
\hline As-Welded & $x$ & $x$ & $x$ & $x$ & $x$ \\
\hline Sensitized ${ }^{a}$ & $x$ & $x$ & $x$ & $x$ & $x$ \\
\hline \multicolumn{6}{|l|}{ Incoloy 800} \\
\hline As-Welded & $x$ & $x$ & $x$ & $x$ & $x$ \\
\hline \multicolumn{6}{|l|}{$410 \mathrm{SS}$} \\
\hline $3 / 4$ Hard $^{b}$ & $x$ & $x$ & $x$ & $x$ & $x$ \\
\hline \multicolumn{6}{|l|}{ Zircaloy 2} \\
\hline As-Received & $x$ & $x$ & $x$ & $x$ & $x$ \\
\hline
\end{tabular}

a $40 \mathrm{hrs}$ at $620^{\circ} \mathrm{C}\left(1150^{\circ} \mathrm{F}\right)$, furnace cool.

${ }^{b} 982^{\circ} \mathrm{C}\left(1800^{\circ} \mathrm{F}\right)$ austenitizing, $556^{\circ} \mathrm{C}\left(1050^{\circ} \mathrm{F}\right)$ temper. 


\section{SPECIMEN HOLDER FABRICATION}

\subsection{RACK CARRIER}

The rack carrier, usually referred to as the "saddlebag," is designed to fit over the turning vane and to act as a container for one or more specimen containers. The carrier is identical to those used previously by GE in other in-reactor test programs at the Dresden 1 plant and was fabricated from 304 SS in accordance with the "G-1" designation of GE drawing $135 \mathrm{C} 5380$, a reduced copy of which is shown in Figure 6-1. The carrier was designated as No. 20, using the binary code on the carrier handle, to remove it numerically from the number sequence of GE carriers which may be returned to the reactor vessel after completion of the plant cleaning operation. Additional drainage holes, not shown on the drawing, were added by Dow after their receipt of the specimens by agreement with Dresden 1 Station personnel.

\subsection{RACK CONTAINERS}

The rack container is designed to fit within the compartments of the carrier and to contain individual specimen racks in a vertical array. The container is identical to those used previously in other GE programs at the Dresden 1 plant and was fabricated from 304 SS in accordance with the "G-2" designation of GE drawing 13C5373, a reduced copy of which is shown in Figure 6-2. The containers were numbered 1 through 6 using a left-justified binary code of punched holes near the handle of the carrier, as shown in Figure 6-3. However, there was a misinterpretation of the binary code when the containers were received by Dow and the Arabic numerals which were metal stamped on the container handles at that time do not correspond to the binary designations. The metal stamped Dow numbers corresponding to the binary container numbers are also shown in Figure 6-3. To clearly distinguish the Dow surveillance program containers and racks from those of GE programs, the Dow binary place markers were punched as diamonds rather than the circular holes used in the GE programs.

\subsection{SPECIMEN RACKS}

The specimen rack is designed to hold the pressurized tube specimens securely in place, while permitting easy rotation and removal of specimens as necessary during examinations. The racks are identical to those used previously in other GE programs at the Dresden 1 plant and were fabricated from 304 SS in accordance with GE drawing 706E738, a reduced copy of which is shown in Figure 6-4. Drainage holes were punched in the back of the racks to facilitate draining of the solvent and rinsing during the plant cleaning operation. The racks were numbered 1 through 25 using the left-justified binary code previously described, and Arabic numerals corresponding to the binary number were metal stamped on each rack at the time of manufacture.

Each rack is designed to hold 13 pressurized tube specimens. However, in this investigation only 12 specimens were loaded in each rack, with the seventh space left empty to separate 2 sets of 6 specimens each. This system permits ready identification of particular specimens within a set. In the case of the $410 \mathrm{SS}$ bent-beam specimens, the 304 SS loading block was tack-welded to the back of the rack, with the specimens oriented parallel to the long direction of the rack. A detailed listing of the individual specimen locations will be presented in Section 8 of this report. 


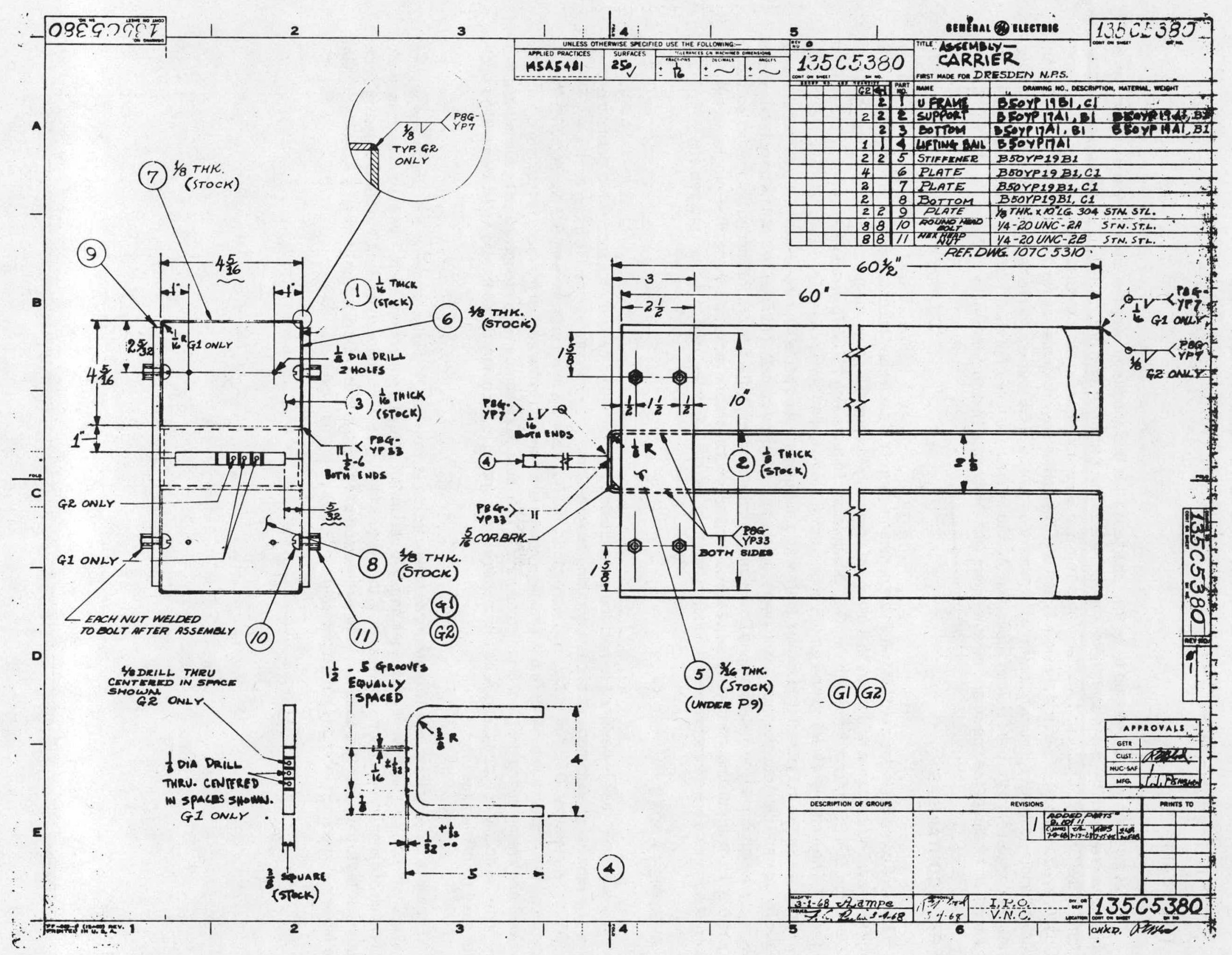

Figure 6-1. Dresden 1 Turning Vane Rack Carrier 


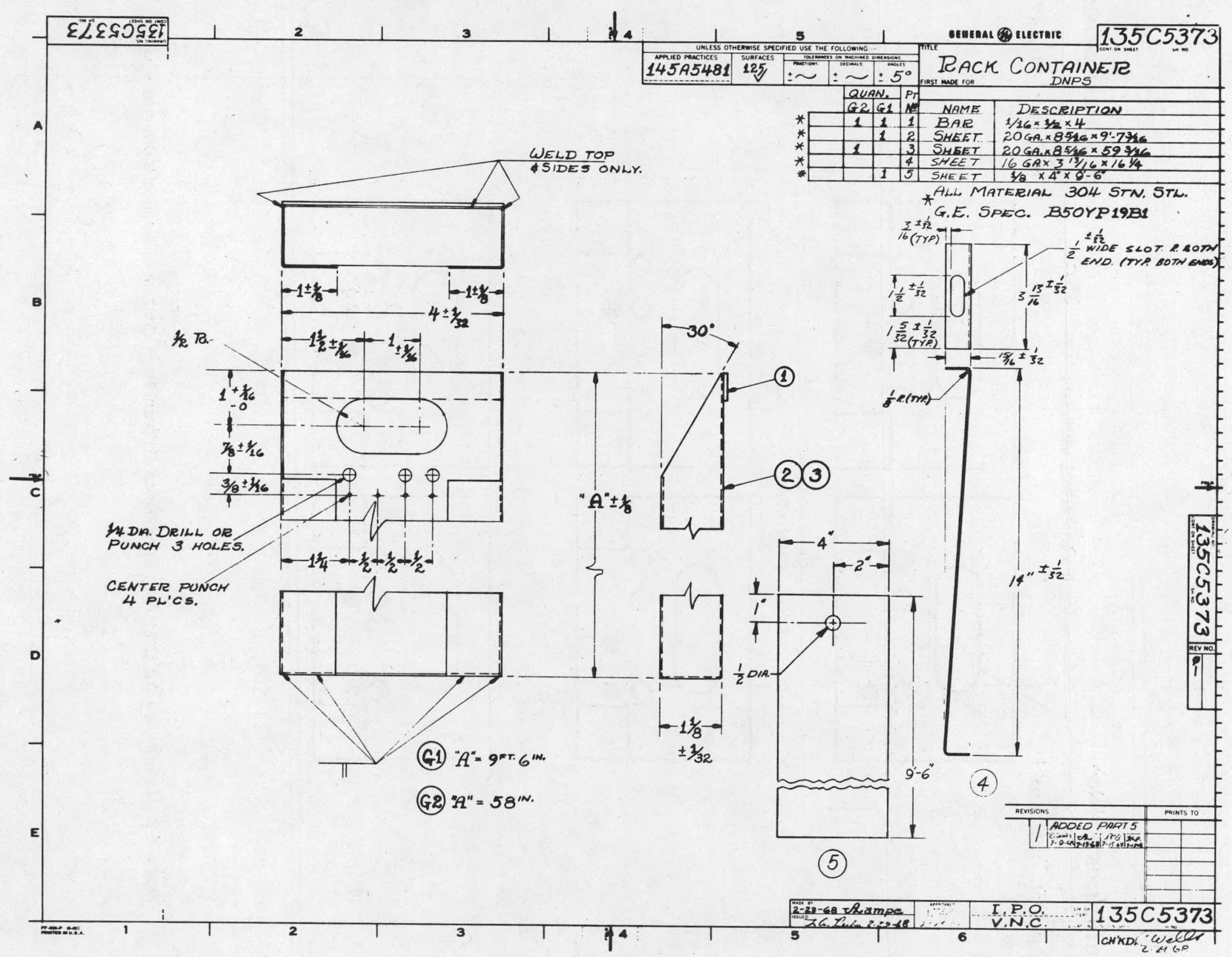

Figure 6-2. Pressurized Tube Rack Container 
IDENTIFICATION NO.

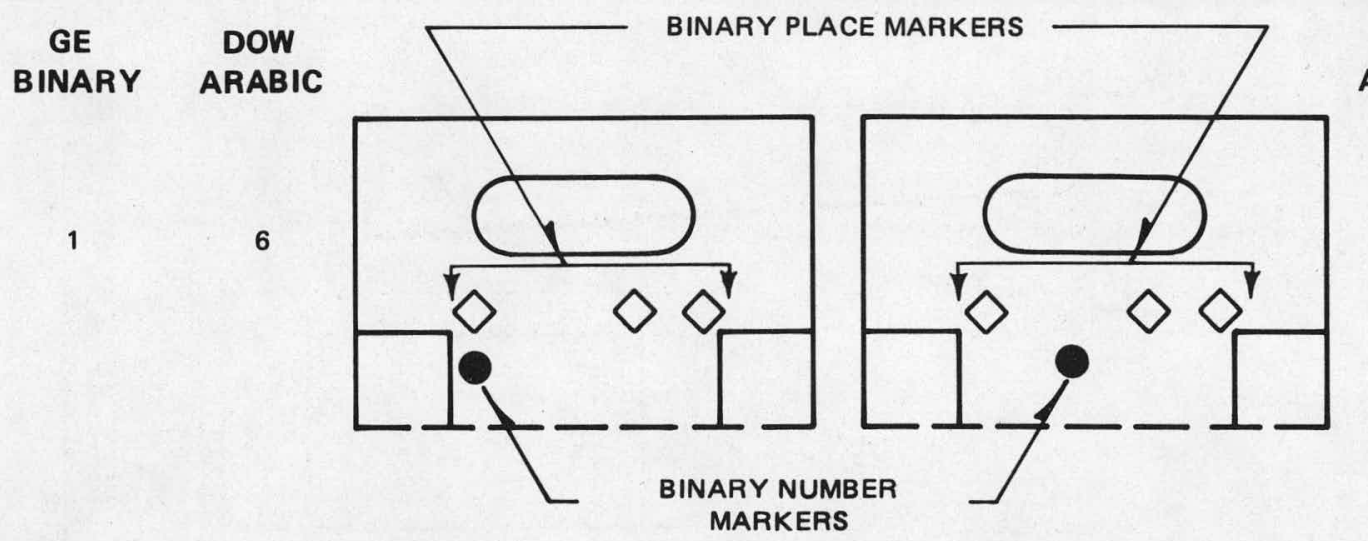

3
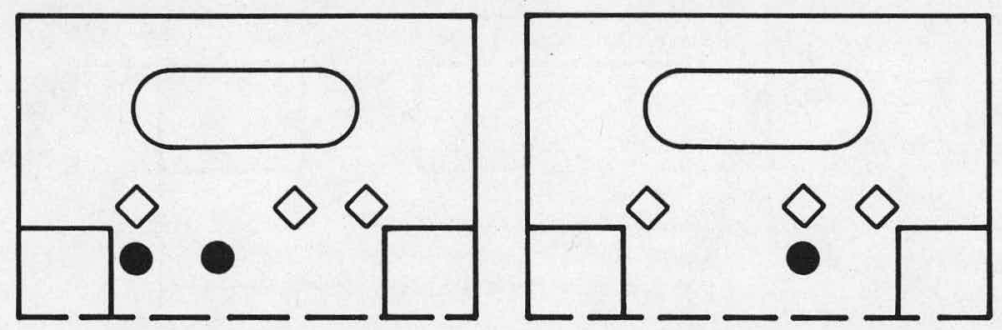

4

2

DOW GE ARABIC BINARY

6 5

Figure 6-3. Dow In-Reactor Long-Term Surveillance Program Rack Container Identification Numbers 


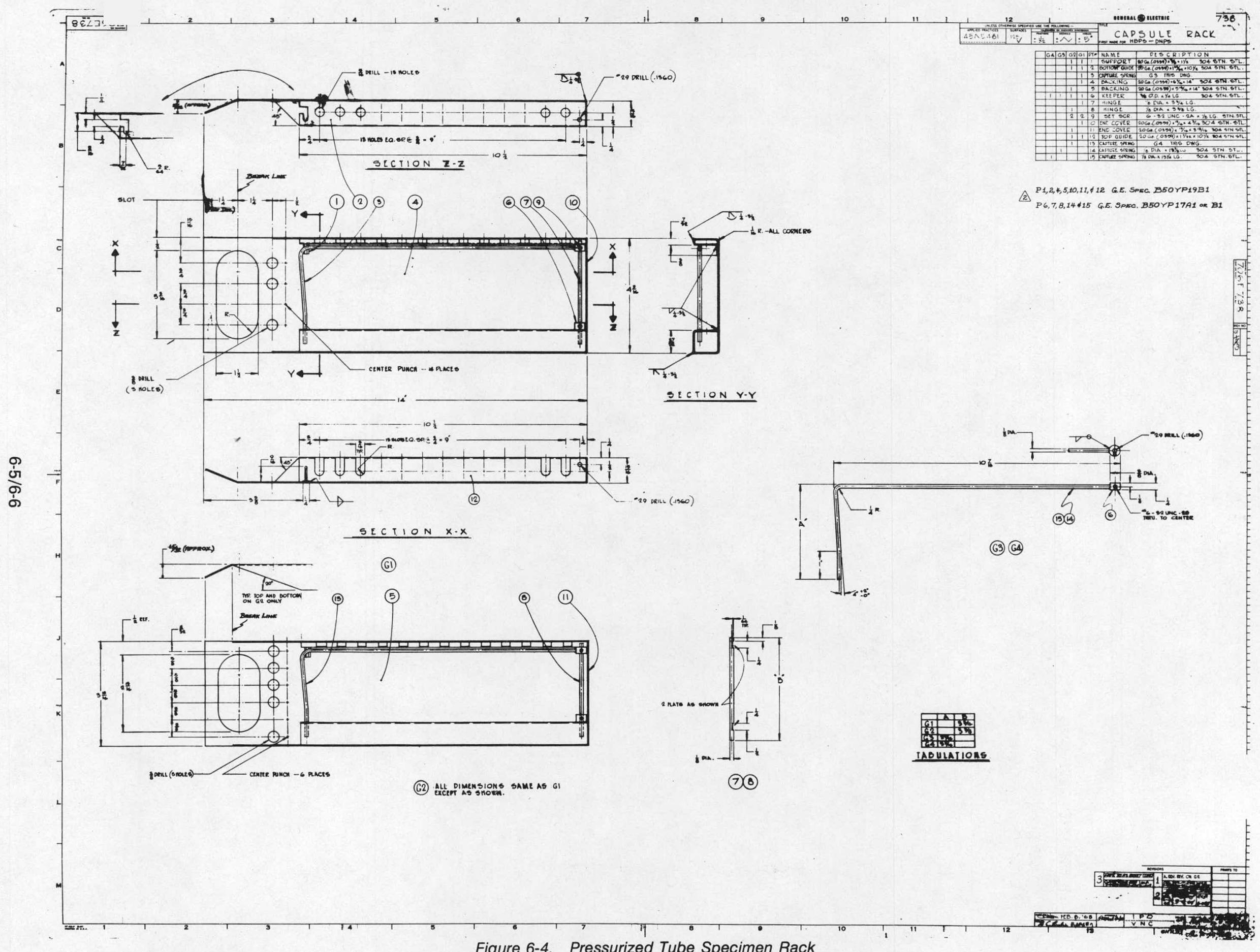




\section{SPECIMEN STRESSING}

\subsection{PRESSURIZED TUBES}

As stated previously, the nominal stress selected for pressurized tube specimens was the $0.2 \%$ offset $Y S$ at $121^{\circ} \mathrm{C}$ $\left(250^{\circ} \mathrm{F}\right)$ for the cleaning cycle specimens, and $288^{\circ} \mathrm{C}\left(550^{\circ} \mathrm{F}\right)$ for the long-term surveillance specimens. The values used for the cleaning cycle specimens were the reported room temperature yield strengths from the mill certification sheets, with the expectation that the change in strength at the higher temperature would be small and in the conservative direction; i.e., if a change occurred over the moderate temperature increase, it would represent a reduction in the true yield strength, and the specimens would be slightly overstressed. The values used for the long-term specimens were those obtained from mechanical properties tests performed on the alloys at $288^{\circ} \mathrm{C}\left(550^{\circ} \mathrm{F}\right)$.

\subsubsection{Calculations}

The formula used to calculate stresses was for thick-walled tubes given by Shigley. ${ }^{6}$ The internal pressure required was calculated to give the desired stress on the outer fibers of the tube, corrected for thermal expansion of the pressurizing gas and external pressures at the cleaning and operating temperatures. The general form of the equation is shown below.

$$
S=\frac{P_{i} \times A^{2}}{B^{2}-A^{2}}\left(\frac{B^{2}}{R^{2}}+1\right)
$$

Where:

$$
\begin{aligned}
& \text { S }=\text { Hoop Stress } \\
& P_{i}=\text { Internal Pressure } \\
& A=\text { Tube Inside Radius } \\
& B=\text { Tube Outside Radius } \\
& R=\text { Radius of the element of interest }
\end{aligned}
$$

For the o.d. fibers, the outside radius and the radius of interest are the same and the equation reduces to:

$$
S=\frac{P_{i} \times A^{2}}{B^{2}-A^{2}} \times 2
$$

Rearranging to solve for $\mathrm{P}_{i}$, and correcting for the external pressure, the equation becomes:

$$
P_{i}=\frac{S\left(B^{2}-A^{2}\right)}{2 A^{2}}+P_{0}
$$

Where:

$$
P_{0}=\text { External pressure }
$$


Assuming that the pressurizing gas obeys the ideal gas law, a correction factor is then inserted to give the correct fill pressure at ambient temperature and the equation becomes:

$$
P_{f}=\frac{\frac{S\left(B^{2}-A^{2}\right)}{2 A^{2}}+P_{o}}{C_{t}}
$$

Where:

$$
\begin{aligned}
& P_{f}=\text { Ambient temperature fill pressure } \\
& C_{t}=\text { Correction Factor for Temperature } \\
& C_{t}=1.331 \text { at } 121^{\circ} \mathrm{C}\left(250^{\circ} \mathrm{F}\right) \\
& C_{t}=1.895 \text { at } 288^{\circ} \mathrm{C}\left(550^{\circ} \mathrm{F}\right) \\
& P_{o}=15 \text { psi at } 121^{\circ} \mathrm{C}\left(250^{\circ} \mathrm{F}\right) \\
& P_{o}=1030 \text { psi at } 288^{\circ} \mathrm{C}\left(550^{\circ} \mathrm{F}\right)
\end{aligned}
$$

Fill pressures for each set of specimens were then calculated, as shown in Table 7-1.

\subsubsection{Tube Pressurizing}

The technician performing the pressurizing operation was instructed to pressurize the specimens to the next highest scale division on the gage, rather than attempting to interpolate exact pressures between scale divisions in $0.07 \mathrm{~Pa}(10 \mathrm{psi})$ increments. Individual specimens were placed in the pressurizing chamber with the seal plug partially threaded into the upper end plug. The chamber and the capsule were pressurized to the desired value and the threaded seal plug was turned until it was tightly seated through a sealed rotating fitting. Argon gas was used as the pressurizing fluid, and each specimen was leak checked after pressurizing by submerging in acetone; with the observance of bubble formation indicating a leak.

\subsection{3 "True" Pressurized Tube Specimen Stresses}

The fill pressures calculated and shown in Table 7-1 were inadvertently obtained using the specified nominal specimen dimensions. This error was not noted until after the specimens had been shipped to Dow, and there was not sufficient time for their return and repressurization because of the schedule for closure of the Dresden 1 RPV. The "true" stresses for the given fill pressures were recalculated for those sets of specimens from which direct dimensional measurements had been made, and the results are shown in Table 7-2. It would appear that the long-term surveillance specimens are actually stressed to a value of 105 to $110 \%$ of the $288^{\circ} \mathrm{C}\left(550^{\circ} \mathrm{F}\right) 0.2 \%$ offset YS.

Similar calculations could not be made for the cleaning cycle specimens because true specimen dimensional checks were not made on any sets from this group. However, because of the consistency exhibited by the specimen fabricator in those sets which were checked, one would expect a similar situation to exist in the cleaning cycle specimens; i.e., the specimens are stressed slightly above the $121^{\circ} \mathrm{C}\left(250^{\circ} \mathrm{F}\right) 0.2 \%$ offset $\mathrm{YS}$.

The $304 \mathrm{~L}$ SS pressurized tube specimens were subject to significantly higher stresses than originally intended because of a records error. The value used for the $288^{\circ} \mathrm{C}\left(550^{\circ} \mathrm{F}\right) 0.2 \%$ YS was obtained from previous studies utilizing this heat of material and was quoted as $163 \mathrm{mPa}(23.6 \mathrm{ksi})$; the required fill pressures were calculated on that basis. During the preparation of this report, design record confirmation of this value was attempted, and no record of the performance of elevated temperature mechanical properties tests on this heat of material could be located. Specimens were prepared and 
tested to generate record data, and the $288^{\circ} \mathrm{C} 0.2 \%$ YS value obtained as a mean of three specimens was $142 \mathrm{mPa}(20.6$ $\mathrm{ksi}$ ). If this mean is used as the true value of the $288^{\circ} \mathrm{C} \mathrm{YS}$, then the $304 \mathrm{~L} \mathrm{SS}$ specimens were stressed to $\sim 115 \%$ of the intended value. This error in true stress level would not affect the conclusions of the program regarding the effects of exposure to NS-1 solvent of subsequent service performance.

\subsection{SS BENT-BEAM SPECIMENS}

These specimens were stressed as fixed deflection constant radius bent beams over 304 SS radius blocks. Mechanical properties tests were made on the heat-treated material, and the total strain at the $0.2 \%$ offset YS was determined at $21^{\circ} \mathrm{C}\left(70^{\circ} \mathrm{F}\right)$ and $288^{\circ} \mathrm{C}\left(550^{\circ} \mathrm{F}\right)$. The difference between these two values was not large, and a single value corresponding to that at $288^{\circ} \mathrm{C}$ was selected for stressing of all $410 \mathrm{SS}$ specimens $(0.70 \%$ strain). The formula used for calculating the strain in the bent beams was as follows:

$$
E=\frac{T}{2 R+T}
$$

Where:

$$
\begin{aligned}
& E=\text { Strain in outer fibers, } \mathrm{cm} / \mathrm{cm} \text { (in./in.) } \\
& T=\text { Specimen thickness } \\
& R=\text { Radius of curvature of loading block }
\end{aligned}
$$

The product form of the $410 \mathrm{SS}$ used was 16 -gage sheet stock, which gave a loading block radius of $11.4 \mathrm{~cm}(4.5 \mathrm{in}$.).

The cleaning cycle specimens and the long-term control specimens were loaded on the constant radius blocks prior to shipment of the specimens to Dow, and the blocks were tack welded into the specimen racks. The long-term cleaning specimens were not loaded on the blocks at this time, but were simply wired into the specimen holders. This procedure was followed based on observations in Dow investigations of increasing general corrosion rates of $3 / 4$ hard 410 SS in the NS-1 solvent at $121^{\circ} \mathrm{C}\left(250^{\circ} \mathrm{F}\right)$ as a function of the stress level. Since loss of specimen thickness would result in lower stresses on the bent-beam specimens, it was decided to minimize that loss on the long-term specimens by exposing them in the unstressed condition and then stressing them prior to the subsequent operating plant exposures. 
Table 7-1

NOMINAL HOOP STRESSES AND FILL PRESSURES OF PRESSURIZED TUBE STRESS-CORROSION CRACKING SURVEILLANCE SPECIMENS

\section{Alloy/Condition}

304 SS

As-Welded

Sensitized ${ }^{d}$

304L SS

As-Welded

Sensitized ${ }^{d}$

Inconel 600

As-Weldedc

Sensitized ${ }^{d}$

Incoloy 800

As-Welded

Zircaloy 2

As-Received

\section{Cleaning Cycle}

Hoop Stress

Fill Pressure

$235 \mathrm{mPA}$ (34.1 ksi)

$235 \mathrm{mPa}$ (34.1 ksi)

$34.5 \mathrm{mPa}(5.0 \mathrm{ksi})$

$30.3 \mathrm{mPa}(4.4 \mathrm{ksi})$

$276 \mathrm{mPa}$ (40.1 ksi)

$37.2 \mathrm{mPa}$ (5.4 ksi)

$37.2 \mathrm{mPa}$ (5.4 ksi)

$163 \mathrm{mPa}(23.6 \mathrm{ksi})$

$163 \mathrm{mPa}$ (23.6 ksi)

$31.0 \mathrm{mPa}(4.5 \mathrm{ksi})$

$276 \mathrm{mPa}$ (40.1 ksi)

$241 \mathrm{mPa}(35.0 \mathrm{ksi})$

$241 \mathrm{mPa}$ (35.0 ksi)

$35.2 \mathrm{mPa}(5.1 \mathrm{ksi})$

$31.0 \mathrm{mPa}$ (4.5 ksi)

$181 \mathrm{mPa}(26.3 \mathrm{ksi})$

$181 \mathrm{mPa}(26.3 \mathrm{ksi})$

$38.6 \mathrm{mPa}(5.6 \mathrm{ksi})$

$34.5 \mathrm{mPa}(5.0 \mathrm{ksi})$

$238 \mathrm{mPa}$ (34.5 ksi)

$31.0 \mathrm{mPa}$ (4.5 ksi)

$145 \mathrm{mPa}(21.1 \mathrm{ksi})$

$28.3 \mathrm{mPa}(4.1 \mathrm{ksi})$

$375 \mathrm{mPa}$ (54.4 ksi)

$49.0 \mathrm{mPa}$ (7.1 ksi)

$155 \mathrm{mPa}$ (22.5 ksi)

$30.3 \mathrm{mPa}(4.4 \mathrm{ksi})$

$121^{\circ} \mathrm{C}\left(250^{\circ} \mathrm{F}\right), 0.1 \mathrm{mPa}(15 \mathrm{psi})$

${ }^{b} 288^{\circ} \mathrm{C}\left(550^{\circ} \mathrm{F}\right), 7.1 \mathrm{mPa}(1030 \mathrm{psi})$

c As-Welded specimens are smaller in diameter than sensitized specimens

d $40 \mathrm{hr} 620^{\circ} \mathrm{C}\left(1150^{\circ} \mathrm{F}\right)$, furnace cool 
Table 7-2

"TRUE" STRESS ON PRESSURIZED TUBE SPECIMENS USING MEAN MEASURED DIMENSIONAL VALUES

\section{Material/Condition}

304 SS

As-Welded

Sensitized ${ }^{b}$

Inconel 600

As-Welded

Sensitized ${ }^{b}$
Fill Pressure

$29.9 \mathrm{mPa}$ (4337 psi)

$26.8 \mathrm{mPa}$ (3890 psi)

$38.7 \mathrm{mPa}$ (5607 psi)

$34.6 \mathrm{mPa}$ (5011 psi)
“True" Stress

$145 \mathrm{mPa}$ (21.0 ksi)

$149 \mathrm{mPa}$ (21.6 ksi)

$192 \mathrm{mPa}$ (27.8 ksi)

$196 \mathrm{mPa}$ (28.4 ksi)
Variance from Nominal Stress

$+6 \%$

$+10 \%$

$+6 \%$

$+8 \%$

${ }^{a}$ Based on mean measured i.d. and o.d. of five tubes from each group

b $40 \mathrm{hr} 620^{\circ} \mathrm{C}\left(1150^{\circ} \mathrm{F}\right)$, furnace cool 


\section{SPECIMEN LOCATIONS}

\subsection{RACK NUMBERING}

As stated in subsection 6.3, the specimen racks were numbered 1 through 25 using a left-justified binary code and were metal stamped with Arabic numerals corresponding to that code. The rack numbers for the different specimen sets are shown in Table 8-1, and examples of the binary code are shown in Figure 8-1.

\subsection{SPECIMEN NUMBERING}

The SCC specimens were numbered sequentially through each alloy and condition with a given alloy. The numbering system used was Arabic, and the specimen numbers were Vibra-Tooled on the bottom capsule plug of the pressurized tubes prior to pressurizing and were metal-stamped on the $410 \mathrm{SS}$ bent beams prior to loading. The specimen numbers were preceded by " $\mathrm{D} 1$ " to identify the individual specimens as part of the Dresden 1 chemical cleaning program. The numbers assigned to the individual specimens are shown in Table 8-2.

\subsection{SPECIMEN LOCATIONS}

The specimen sets were loaded sequentially in the racks beginning with the position nearest the rack handle; when the rack contained two sets of specimens they were separated by an empty space, as shown in Figure 8-1. With the exception of the Incoloy 800 , and one set of severely sensitized 304 SS, full sets of specimens were loaded for all alloys and conditions.

Considerable difficulty was encountered in the sealing and pressurizing of the Incoloy 800 specimens. The production of sound closure welds was difficult and a number of specimens had to be re-welded. In addition, the original plate weld exhibited a large number of defects, and the re-welding of capsule bodies to correct this condition was not possible. While the closure weld problem was eventually solved, there were insufficient spare specimens to account for those lost because of original weld defects, and the Incoloy 800 specimen set is incomplete. Two specimens (Nos. 185 and 186) are missing from rack No. 16, one specimen (No. 194) is missing from rack No. 18, and two specimens (Nos. 205 and 207) are missing from rack No. 20. A single specimen (No. 36) of severely sensitized 304 SS is missing from rack No. 1.

Sketches showing the locations of specimens in each individual rack are presented as Appendix B. In addition, the fill pressure recorded by the technician for each tube is shown as a parenthesized value in each specimen location, expressed as pounds per square inch. 


\section{Table 8-1}

STRESS-CORROSION CRACKING SURVEILLANCE PROGRAM

SPECIMEN RACK NUMBERS

\section{Alloy/Condition}

304 SS

As-Welded

Sensitized

304L SS

As-Welded

Sensitized

Inconel 600

As-Welded

Sensitized

Incoloy 800

As-Welded

410 SS

$3 / 4$ Hard

Zircaloy 2

As-Received

\section{Cleaning \\ Cycle}

RPV

Control

2

1

6

6

7

7

11

11

16

16

21

17

22

\section{RPV}

Cleaning

3

3

8

8

13

13

18

18

23

\section{B-Loop}

Control

4

4

5

5

10

10
15

15

20

14

14

19

19

20

24

25 
Table 8-2

STRESS-CORROSION CRACKING SURVEILLANCE PROGRAM SPECIMEN NUMBERS

\begin{tabular}{|c|c|c|c|c|c|}
\hline Alloy/Condition & $\begin{array}{c}\text { Cleaning } \\
\text { Cycle }\end{array}$ & $\begin{array}{c}\text { RPV } \\
\text { Control }\end{array}$ & $\begin{array}{c}\text { RPV } \\
\text { Cleaning }\end{array}$ & $\begin{array}{l}\text { B-Loop } \\
\text { Control }\end{array}$ & $\begin{array}{l}\text { B-Loop } \\
\text { Cleaning }\end{array}$ \\
\hline \multicolumn{6}{|l|}{304 SS } \\
\hline As-Welded & $1-6$ & $7-12$ & $13-18$ & $19-24$ & $25-30$ \\
\hline Sensitized & $31-36$ & $37-42$ & $43-48$ & $49-54$ & $55-60$ \\
\hline \multicolumn{6}{|l|}{ 304L SS } \\
\hline As-Welded & $61-66$ & $67-72$ & $73-78$ & $79-84$ & $85-90$ \\
\hline Sensitized & $91-96$ & $97-102$ & $103-108$ & $109-114$ & $115-120$ \\
\hline \multicolumn{6}{|l|}{ Inconel 600} \\
\hline As-Welded & $121-126$ & $127-132$ & $133-138$ & $139-144$ & $145-150$ \\
\hline Sensitized & $151-156$ & $157-162$ & $163-168$ & $169-174$ & $175-180$ \\
\hline \multicolumn{6}{|l|}{ Incoloy 800} \\
\hline As-Welded & $181-186$ & $187-192$ & $193-198$ & $199-204$ & $205-210$ \\
\hline \multicolumn{6}{|l|}{410 SS } \\
\hline 3/4 Hard & $211-216$ & $217-222$ & $223-228$ & $229-234$ & $235-240$ \\
\hline \multicolumn{6}{|l|}{ Zircaloy 2} \\
\hline As-Received & $241-246$ & $247-252$ & $253-258$ & $259-264$ & $265-270$ \\
\hline
\end{tabular}

Example: Specimen D1-45 is a furnace sensitized 304 specimen in the set subjected to the cleaning cycle, followed by service exposure, in the reactor. It would be located in Rack No. 3 from Table 8-1. 


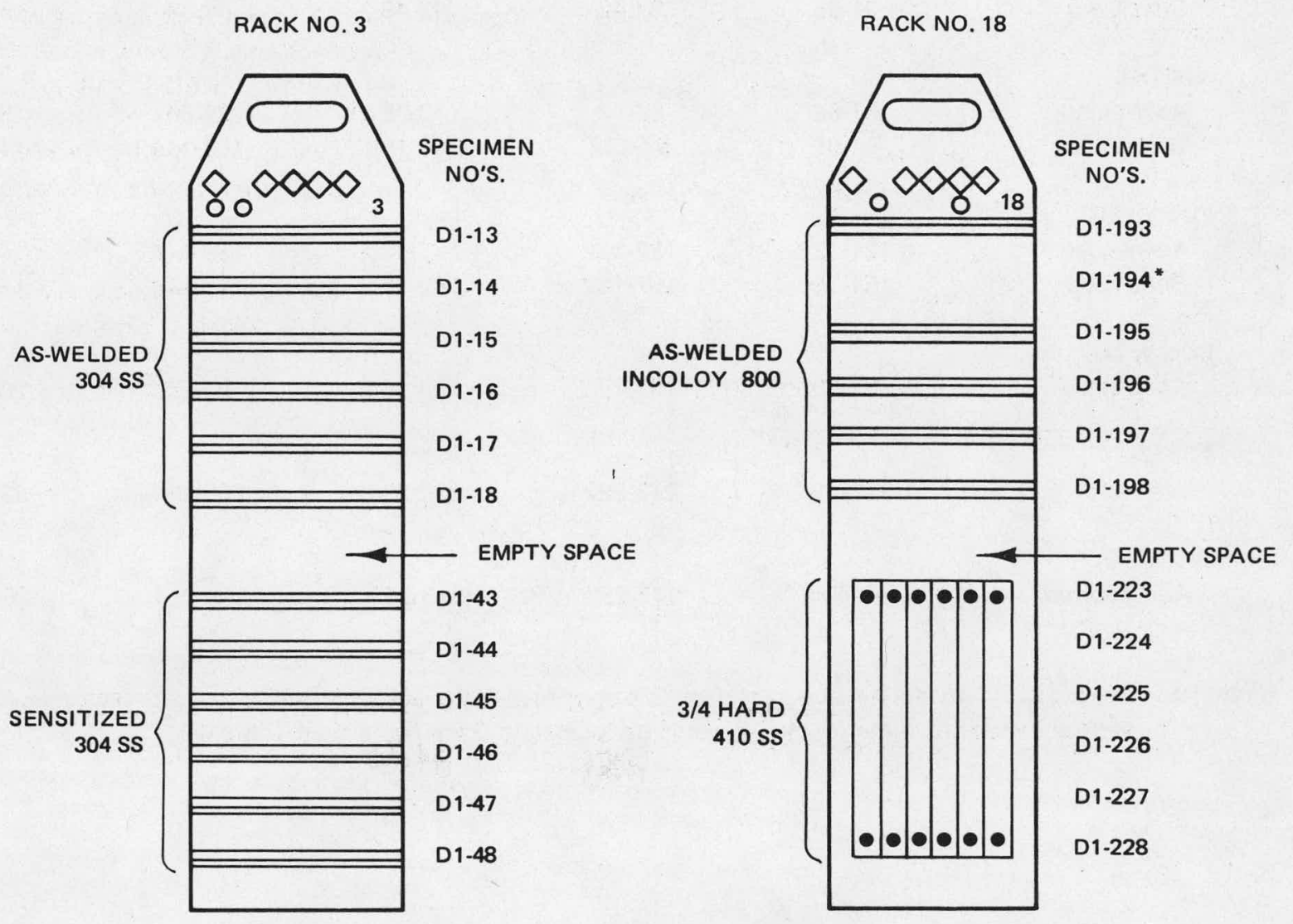

* SPECIMEN D1-194 IS MISSING FROM RACK 18

Figure 8-1. Sketches of Specimen Racks 3 and 18 Showing Specific Specimen Sequences and Arrangements 


\section{REFERENCES}

1. Technical Study for the Chemical Cleaning of Dresden 1, Dow Nuclear Services, Vols. II, IV, V, VI, VIII, June 1977 (DNS-D1-016).

2. The Chemical Cleaning of the Corrosion Fatigue Loop at Dresden 1, Dow Nuclear Services, Vol. 1, August 1978 (DNS-D1-019).

3. W. L. Walker, Dresden 1 Radiation Level Reduction Program: Intergranular Corrosion Tests of Sensitized Type 304 Stainless Steel in Dow NS-1, and Stress Corrosion Cracking Tests of Type 304 Stainless Steel and Carbon and Low Alloy Steels in Dow Copper Rinse Solution, General Electric Co., September 1978 (NEDC-24143).

4. W. L. Walker, Dresden 1 Radiation Level Reduction Program: Long Term Evaluation of the Effects of Exposure to Dow NS-1 Solvent on'the Stress Corrosion Cracking of Sensitized Type 304 Stainless Steel in Simulated BWR Environment, General Electric Co., November 1978 (NEDC-24159).

5. W. L. Walker, Correlation Analyses of Mechanical Properties, General Intergranular Corrosion, and Intergranular Stress Corrosion Cracking Data from Multiple Heats of Type 304 Stainless Steel, General Electric Co., July 1973 (NEDM-13347).

6. J. E. Shigley, Machine Design, McGraw-Hill, New York, 1956, p. 462-466. 
NEDC-24644

APPENDIX A

MILL CERTIFICATION OF TEST MATERIALS

A-1/A-2 


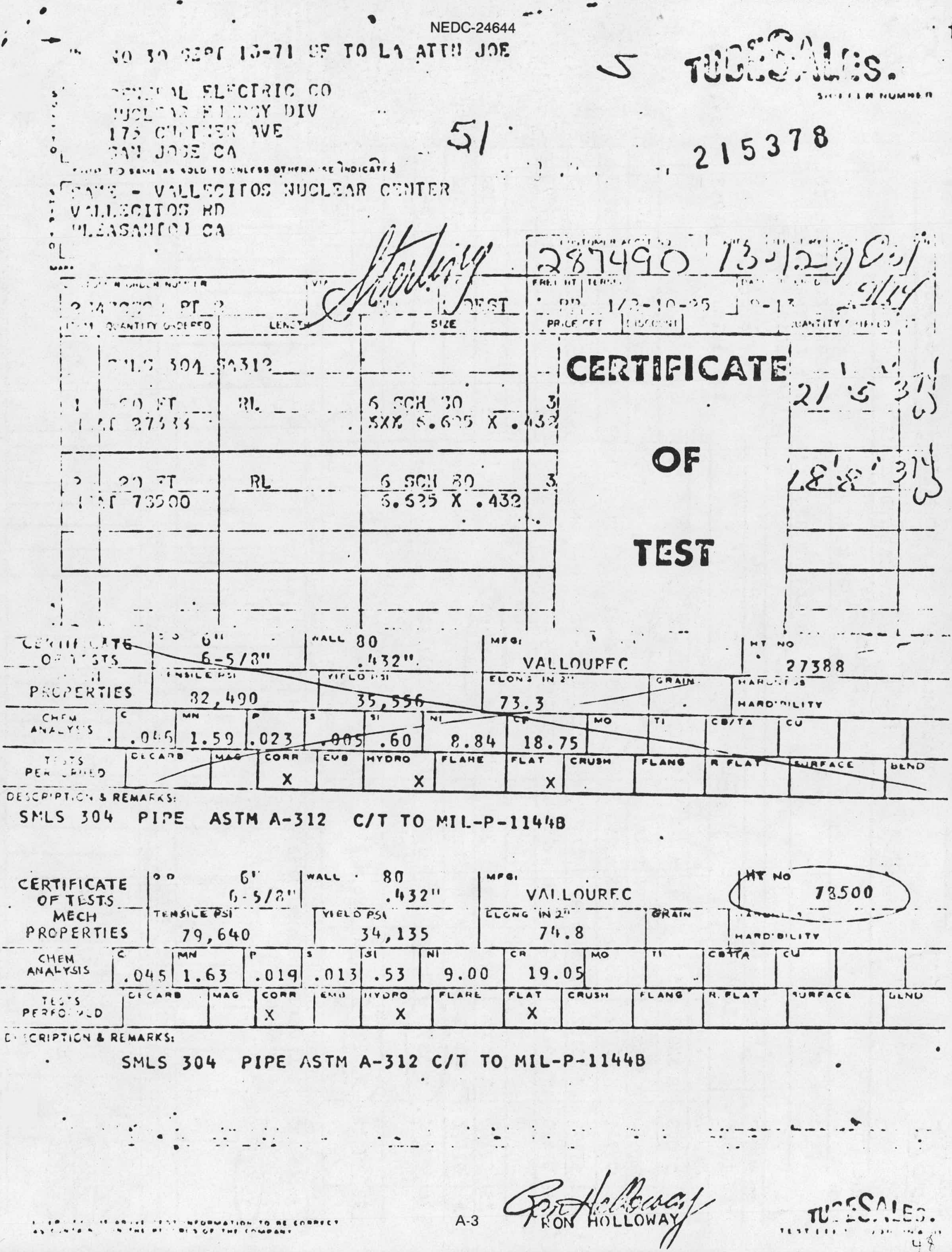




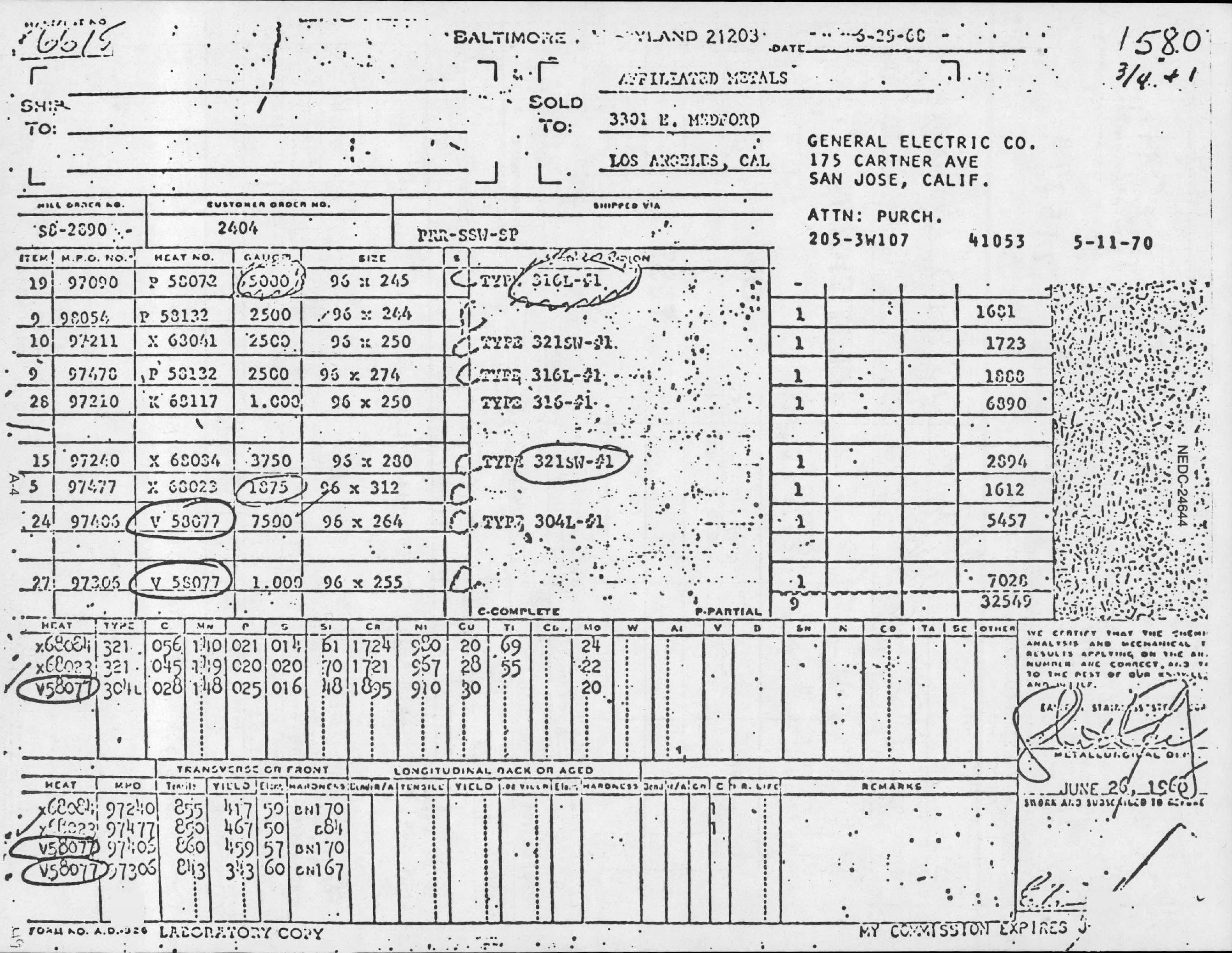




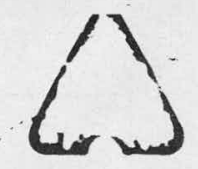

RECEIV ExpUn:

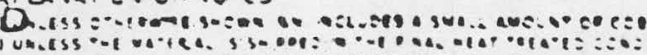

$\begin{array}{ll} & 0\end{array}$

AUG 16197

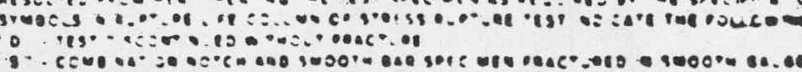

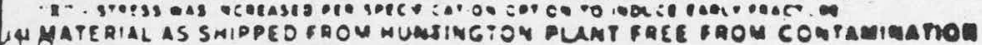

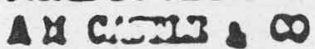

$2 \approx 000 \pi$

nid

comar matiste $\infty$.

varúctes 50.

PUsiskinces/ cis.

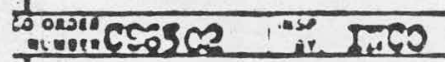

190 SB-167

$891022^{\circ}$ W. L. WAL

\begin{tabular}{|c|c|}
\hline DATE: MeSn-T2"aGe? & $\infty 2$ \\
\hline
\end{tabular}

$284 \cos 28$

CERTIFICATE

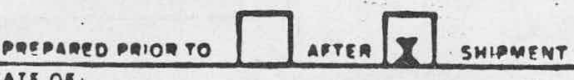

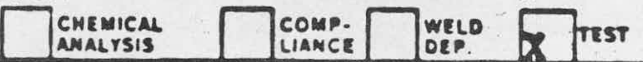

atu

DESCR.PTIOY OF MATERIAL SH PDED

5334

$0.000^{\mathrm{m}}$ OD I 5.225

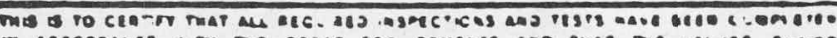

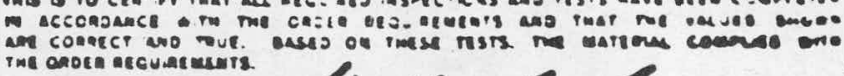

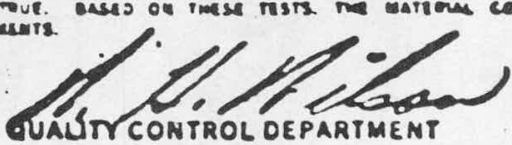
(

-

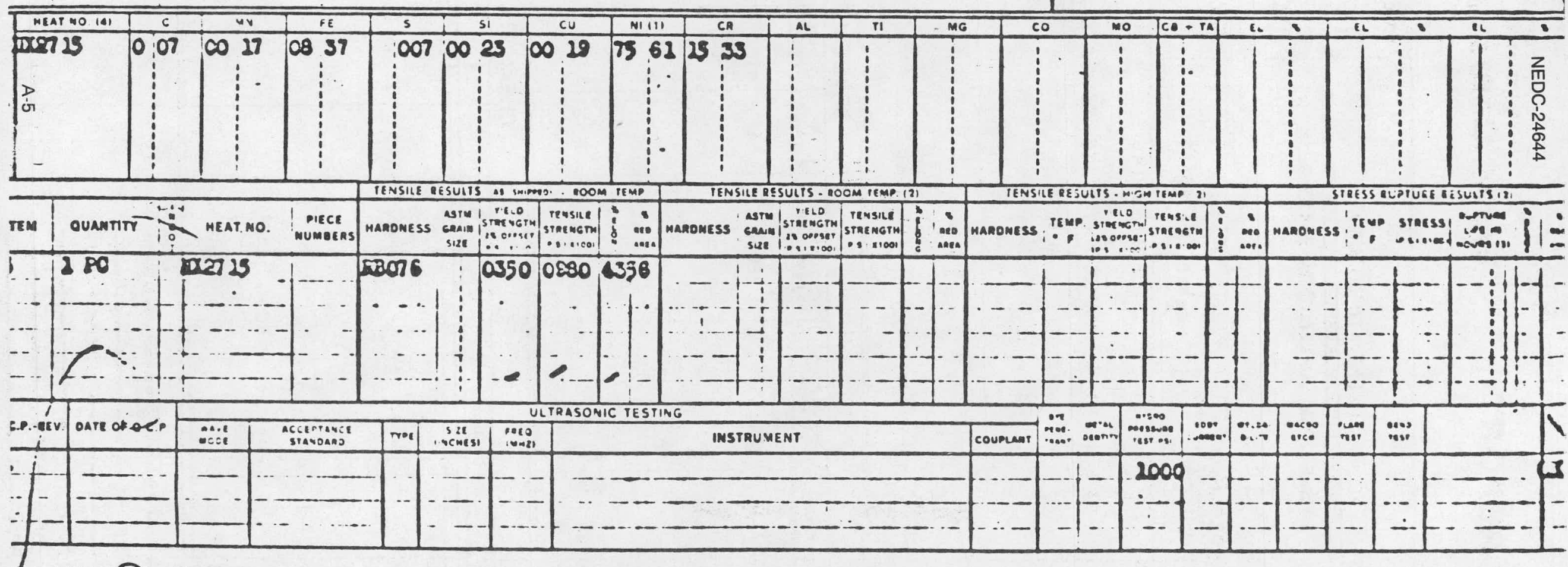

- Duglicete cupie $t / 3 / 2 n$ 


\section{EARLE M. JORGENSEN CO. STEEL}

\section{CERTIFIED MATERIAL TEST REPORT}

GENERAL ELEC

NUCLEAR ENERGY DIV

175 CURIMNER AV MC 116

SAN JOSE CA 95114

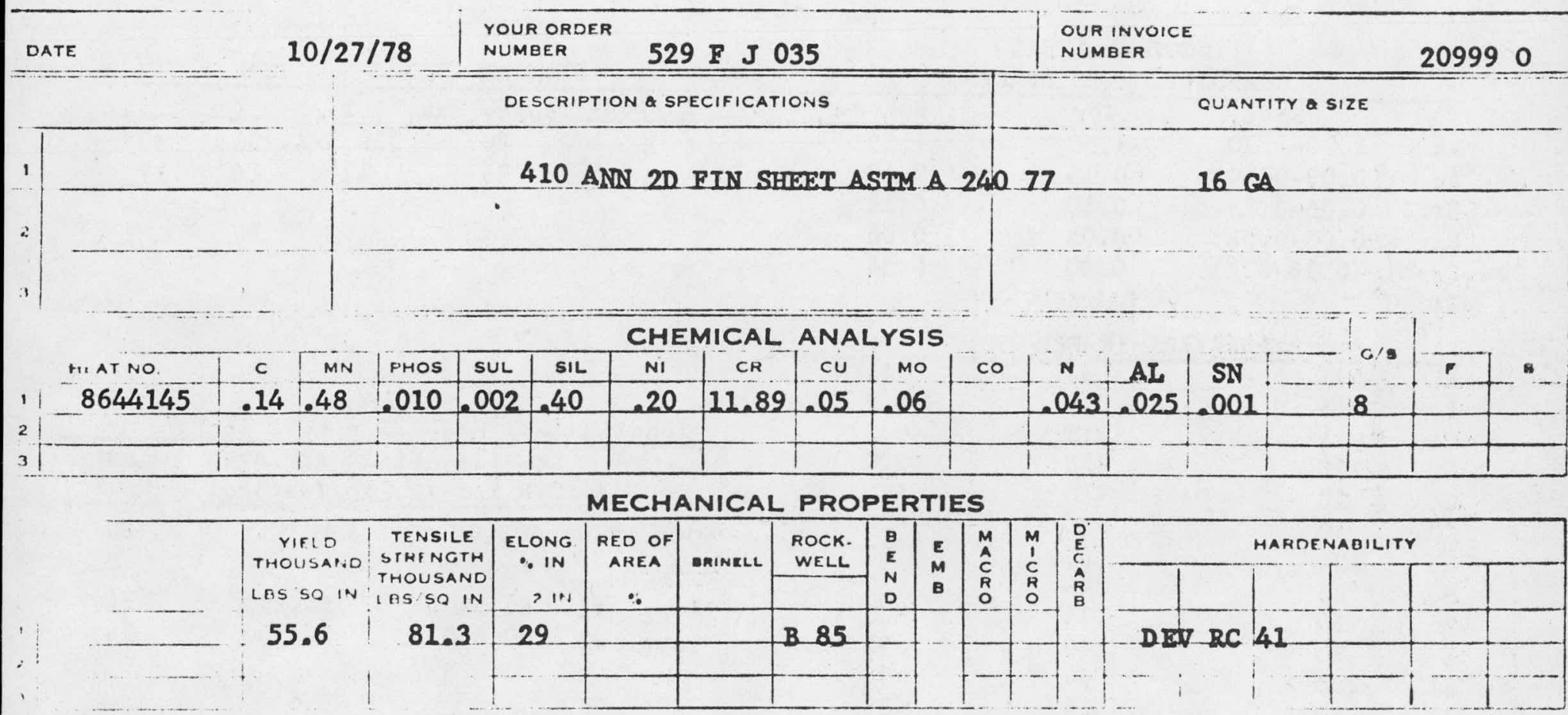

We hereby certify that the material covered by this report has been inspected in accordance with, and has been found to meet, the requirements described herein, including any specifications forming o part of the description, and test resulfs are on file subjoct to examination.

SUBSCRIBED AND SWORN TO BEFORE ME

THIS

DAY OF 10

NOTARY PUBLIC

MY COMMISSION EXPIRES
CERTIFIED MATERIAL TEST REPORT

EARLE M. JORGENSEN CO.

BY STOCK RECORDS SUPERVISOR 
ro

ADOAES
General Electrdc Company

Vallecltos Nuclear Center

Vallectros Road

Pleasanton, CA 94566
PNTELEDYNE WAH CHANG ALBANY

P. $0.80 \times 460$

ALBANY, OAEGON 97321

(803) 926-4211 TWX (810) 505-0973

AtTEnTION of. Femando Velez

IN REGARD TO YOUA PUACHASE ONDER NO S29-V3A2O

ITEM NO 1

* oescaiption ZI 2 Rod

DIMENSIONS

SPECIFICATIONS

$1 / 2^{\prime \prime}$ min. dla. $\times 4$ to $5 \mathrm{ft} . \mathrm{R} / \mathrm{L}$ ASTM B 351-67\& P.0.

THE TEST AEPONT FOLLOWB:

*Hot worked, cold flalshed anealed.
DATE

DATE SHIPPED

OUANTITY SHIPPED

PRODUCTION ORDER NO

HEATNO $397208 Q \quad Z \pi 2$

Macs No. 48601

Anneal Run No. 7835
July 16, 1976

Ref. P.L. /

2 pcs. $6.41 \mathrm{bs}$.

2232

INGOT ANALYSIS COMPOSITION IN PERCENT

\begin{tabular}{|c|c|c|c|}
\hline & Spec. & TOP & Bottom \\
\hline $\mathrm{Sa}$ & $1.20-1.70$ & 1.50 & 1.53 \\
\hline Fe & $0.07-0.20$ & 0.15 & 0.17 \\
\hline$C_{r}$ & $0.05-0.15$ & 0.10 & 0.11 \\
\hline N1 & $0.03-0.08$ & 0.05 & 0.06 \\
\hline$+\mathrm{Cr}_{\mathrm{r}}-\mathrm{N} 1$ & $0.18-0.38$ & 0.30 & 0.34 \\
\hline $2 r$ & & BALANCE & \\
\hline
\end{tabular}

PRODUCT CHEMISTRY, PPM

\begin{tabular}{|c|c|c|c|c|}
\hline Element & Spec. Max: & 1 & 2 & 3 \\
\hline $\begin{array}{l}N \\
\mathrm{H}\end{array}$ & $\begin{array}{l}80 \\
25\end{array}$ & $\begin{array}{c}3 \overline{3 R, 39 R} \\
13\end{array}$ & $\begin{array}{l}36 \\
18\end{array}$ & $\begin{array}{l}33 \\
15\end{array}$ \\
\hline
\end{tabular}

0.3 .

$<0.2$

100

$<10$

22

67

7

$<25$

32

75

$<25$

$<25$

$<25$
TENSILE TEST RESULTS C ROOM TEMP.

\begin{tabular}{|c|c|c|c|}
\hline & $\begin{array}{l}\text { Tensile } \\
\text { STR Ps1 } \\
\end{array}$ & $\begin{array}{l}\text { Yleld strength } \\
(0.2 \% \text { offset)Ps1 } \\
\end{array}$ & $\begin{array}{l}\text { Elong. } \\
\text { In \% }\end{array}$ \\
\hline $\begin{array}{l}\text { Spec. Min: } \\
\text { Sample } \\
\end{array}$ & $: 60,000$ & 35,000 & 14 \\
\hline $\begin{array}{l}\operatorname{Long} . \$ 1 \\
\operatorname{Long} . \$ 2\end{array}$ & $\begin{array}{l}80,500 \\
80,600\end{array}$ & $\begin{array}{l}54,200 \\
54,500\end{array}$ & $\begin{array}{l}24 \\
24\end{array}$ \\
\hline
\end{tabular}

RECEIVED

AUG 16

W. L. WALKE:? 
NEDC-24644

APPENDIX B

DETAILED SKETCHES OF INDIVIDUAL RACK CONTENTS

B-1/B-2 


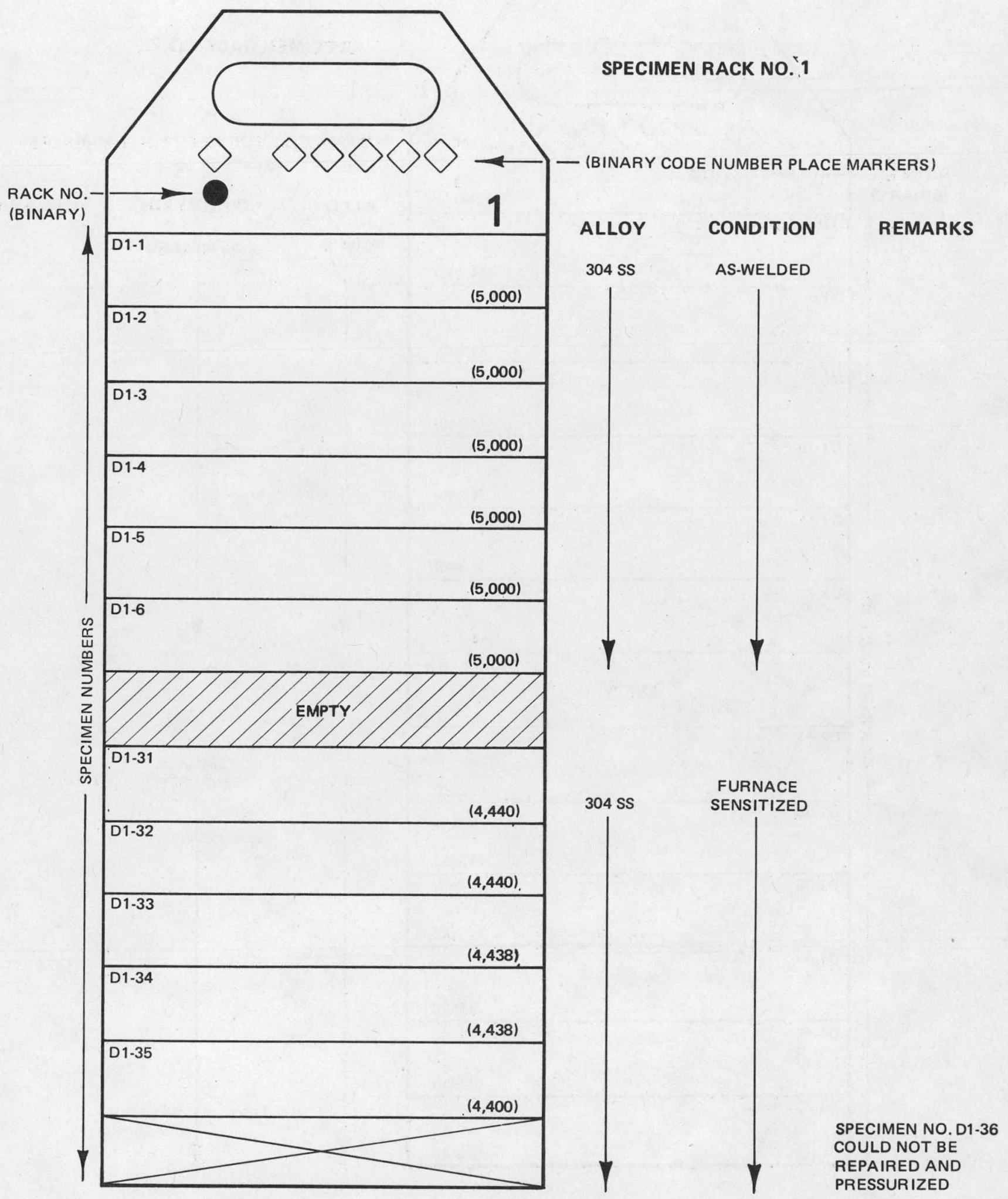




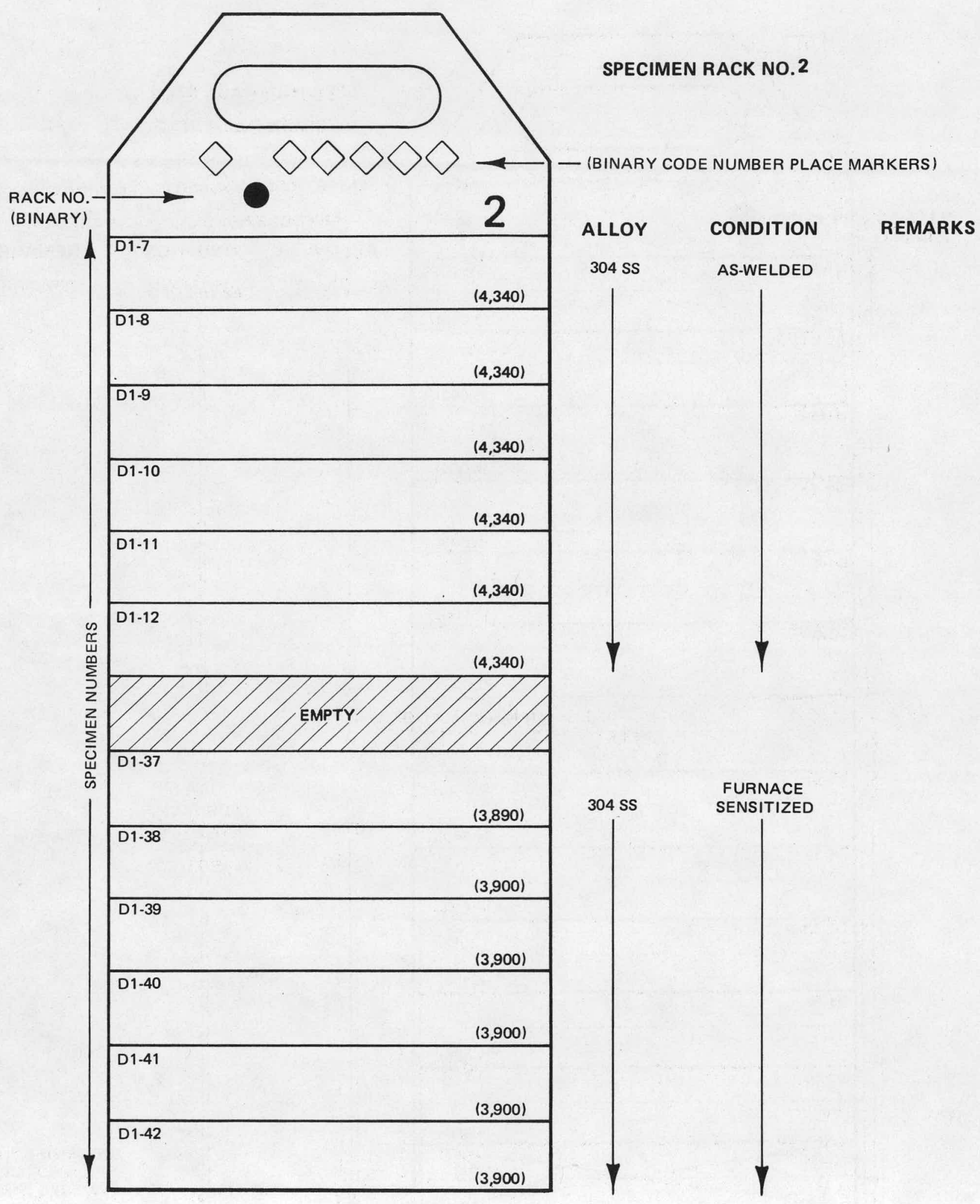




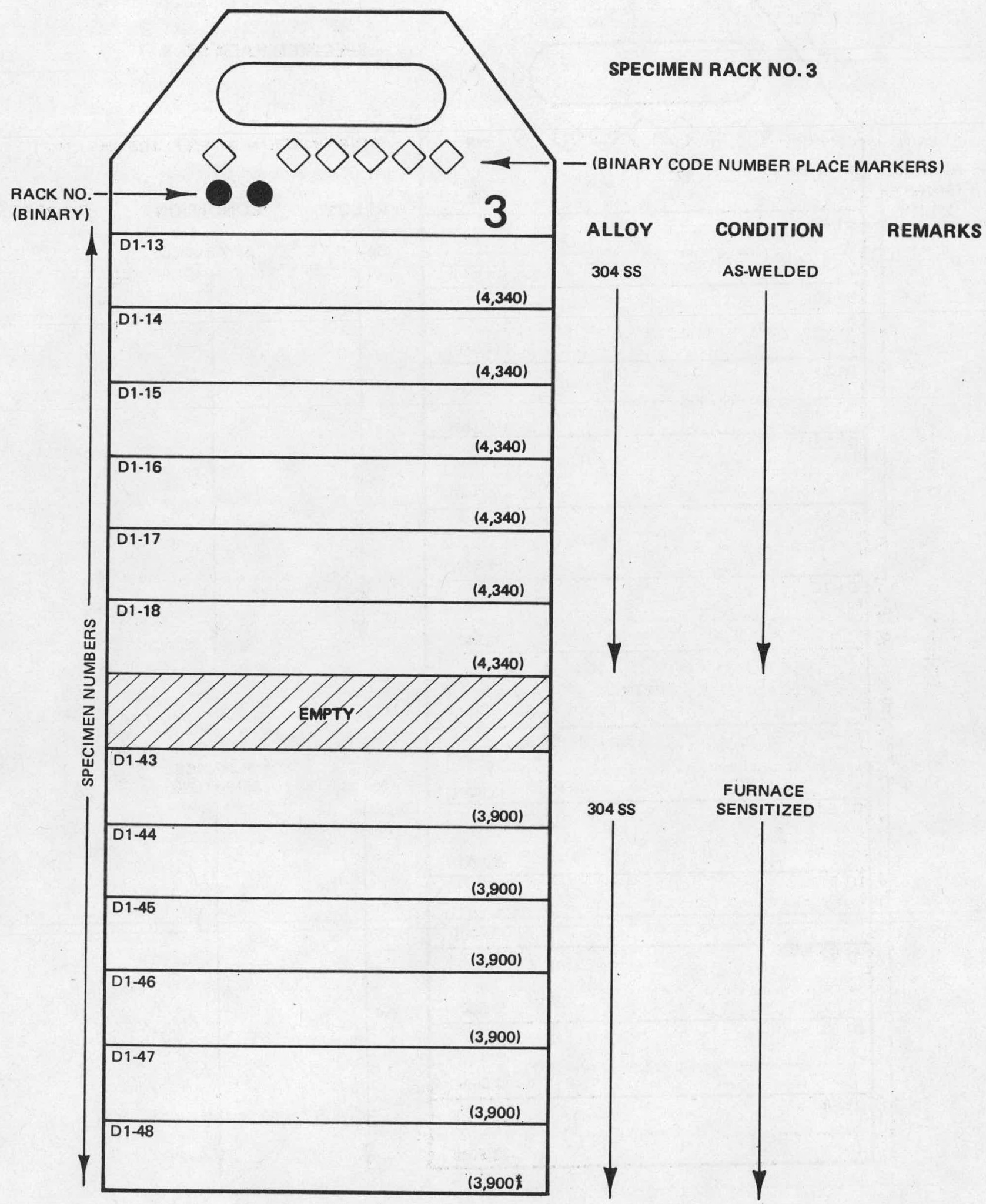




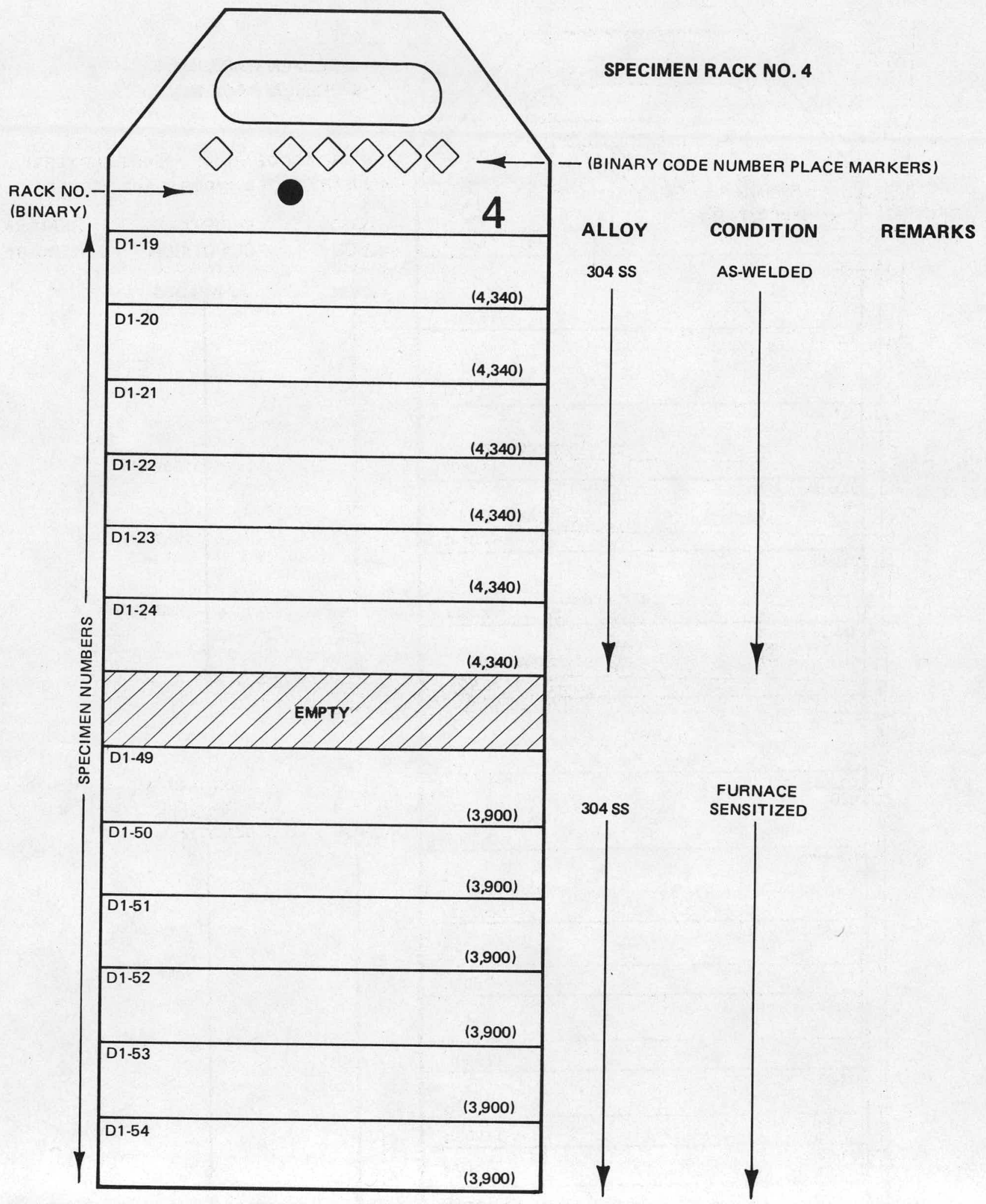




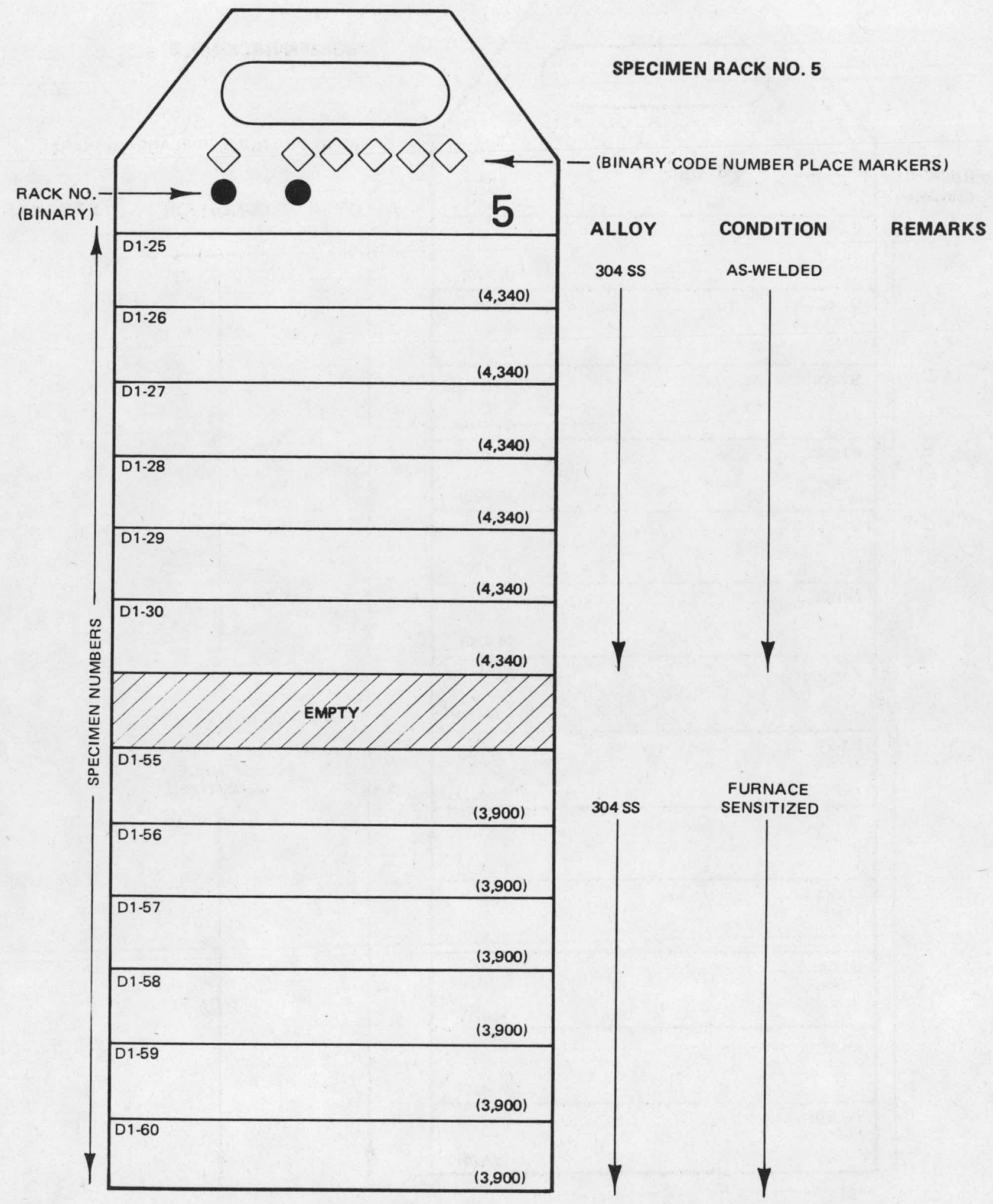




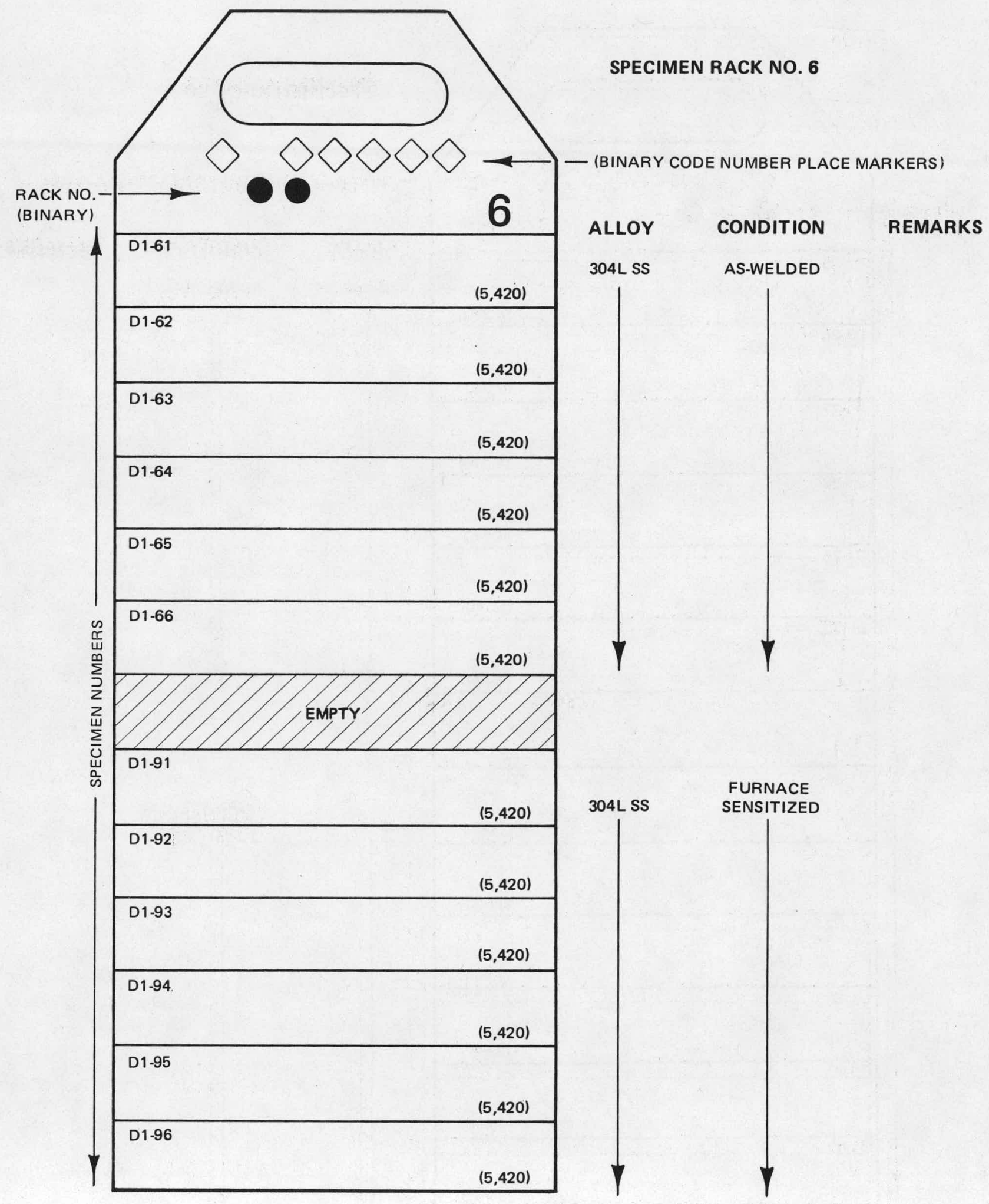




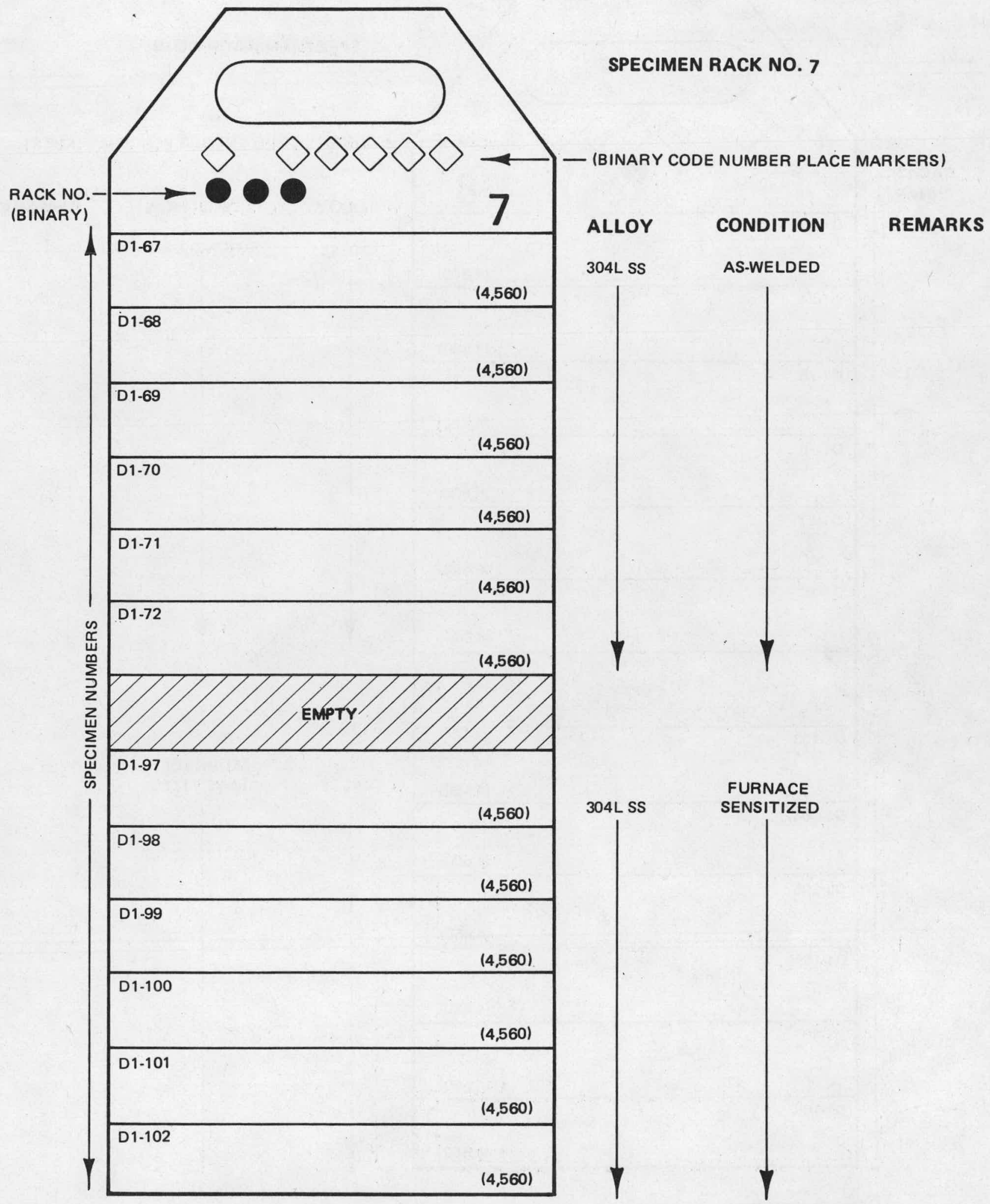




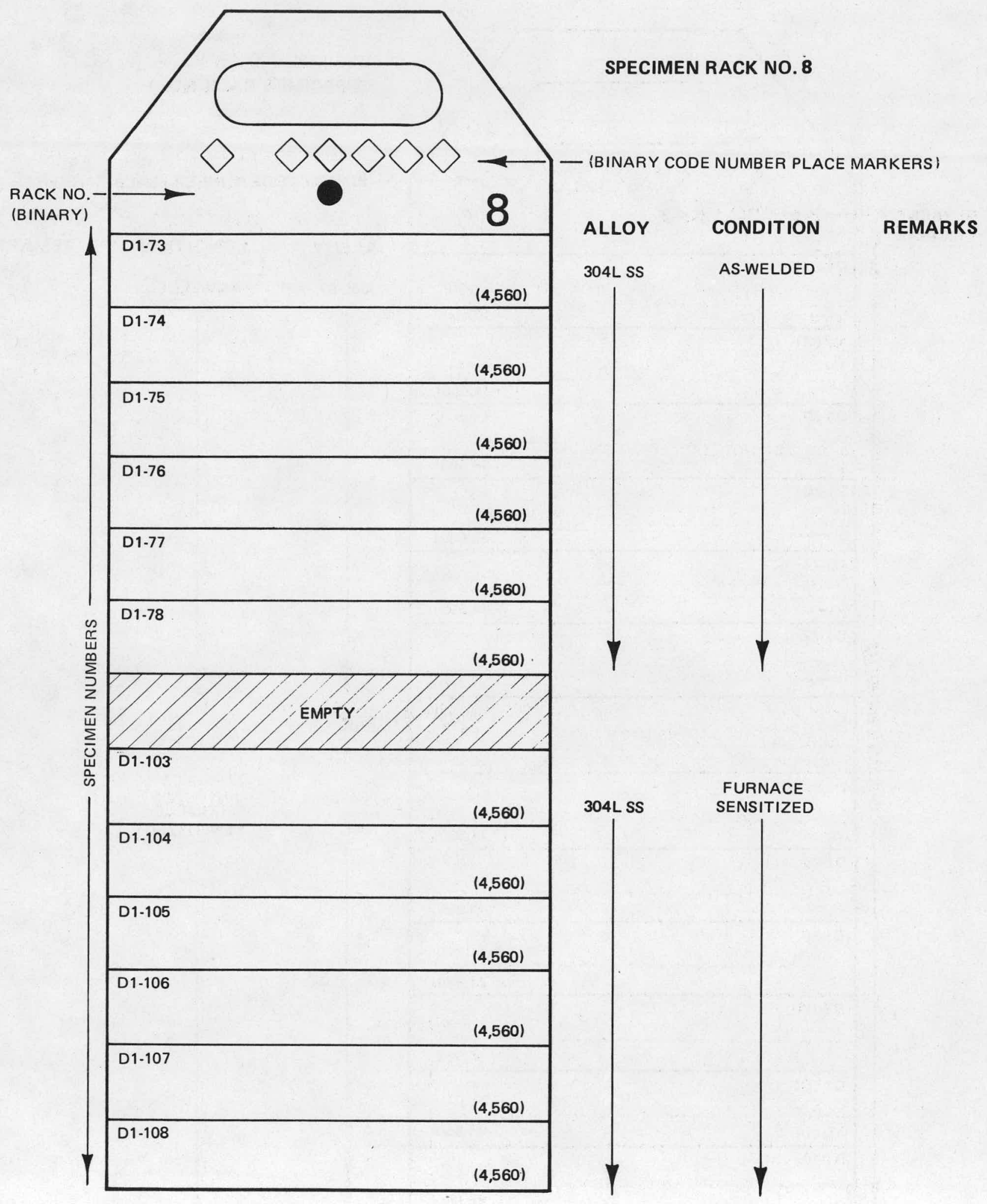




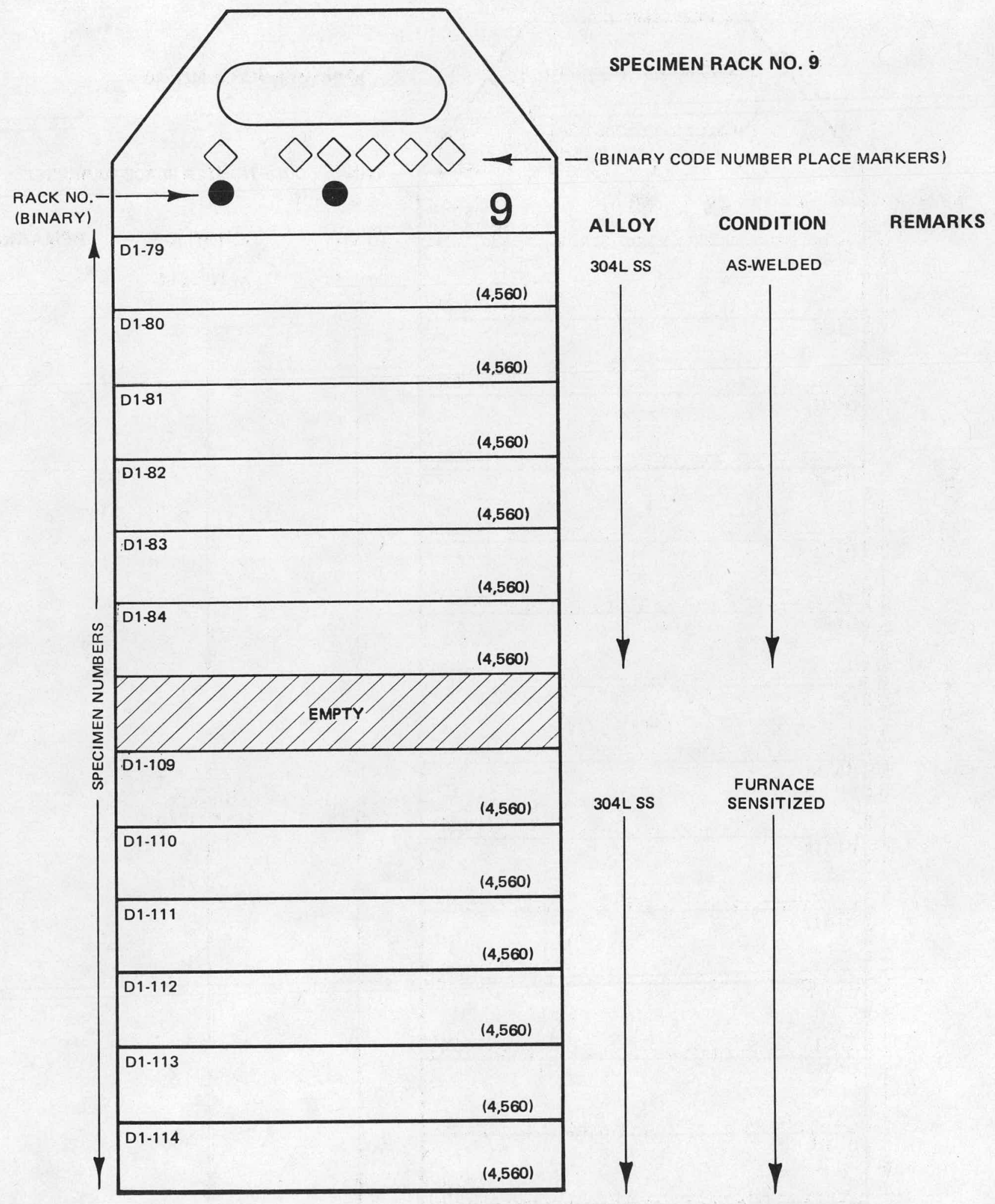




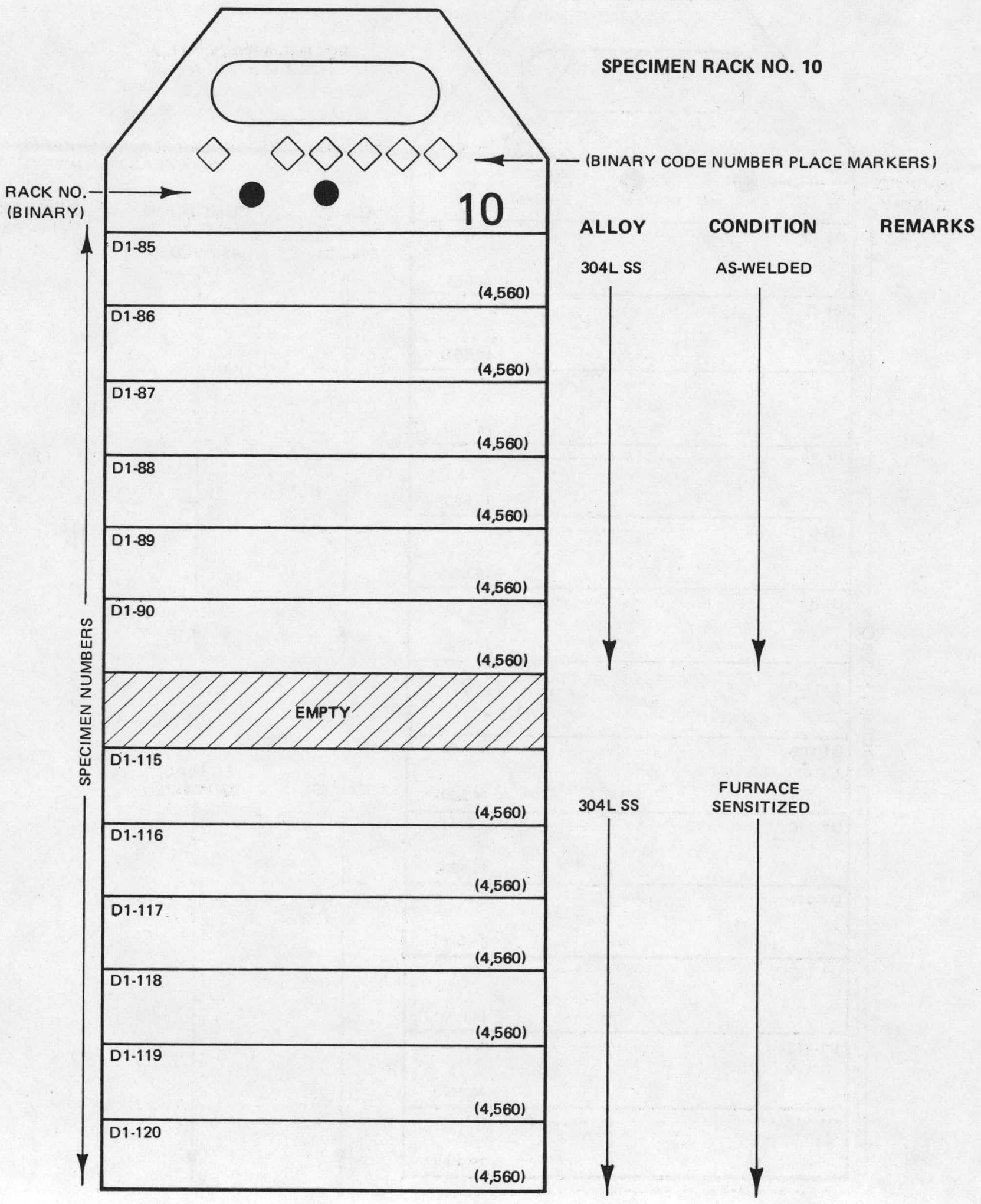




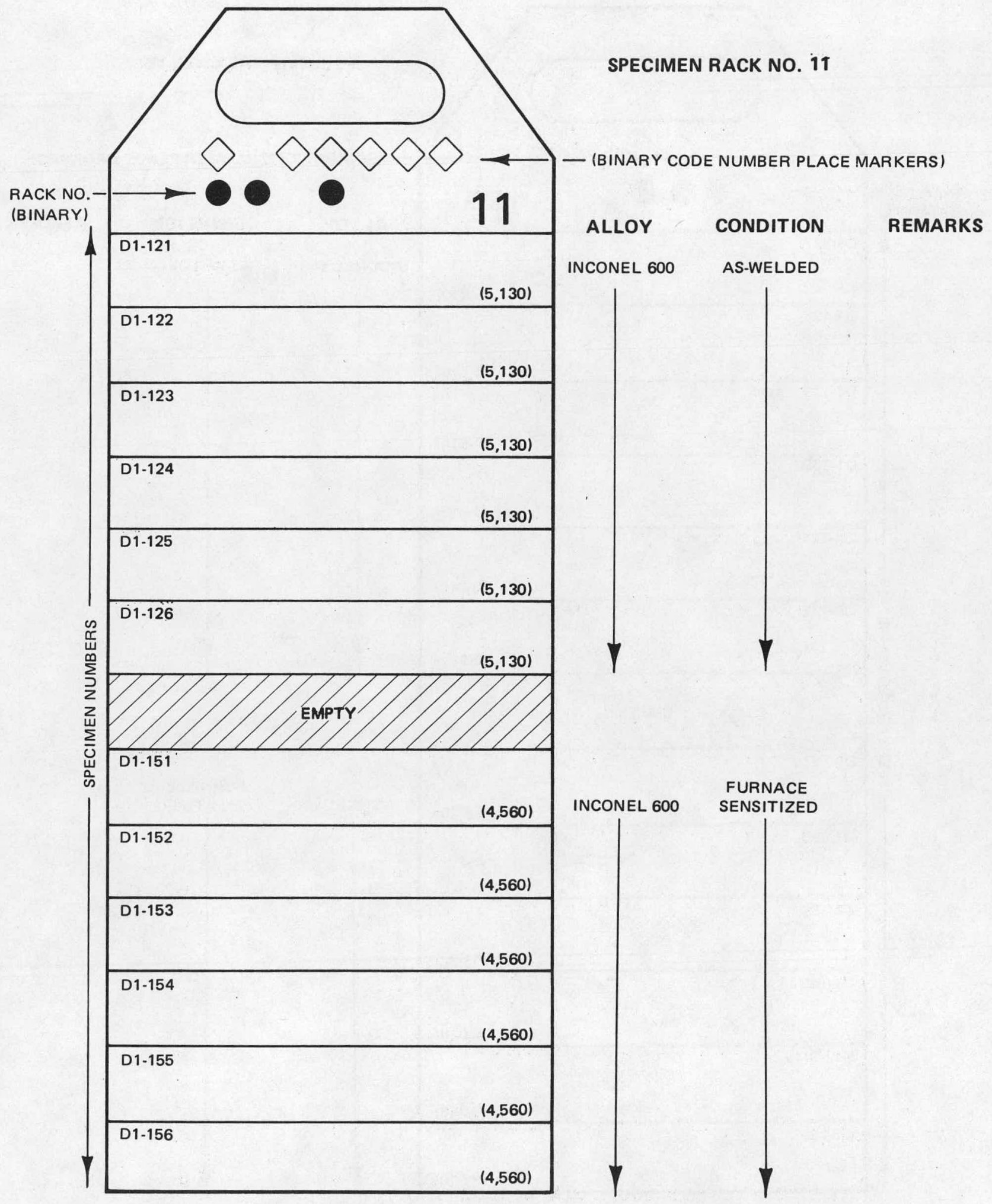




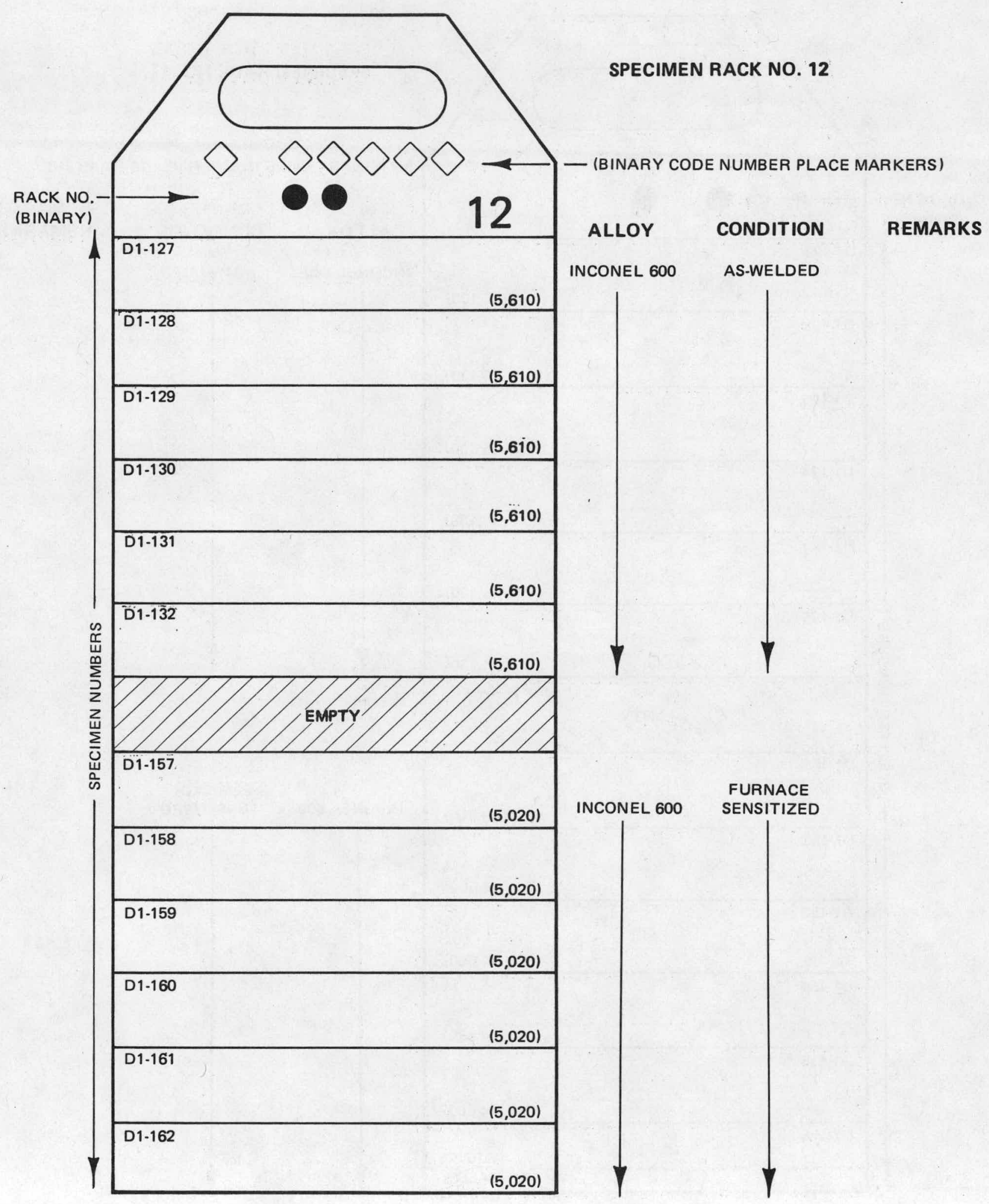




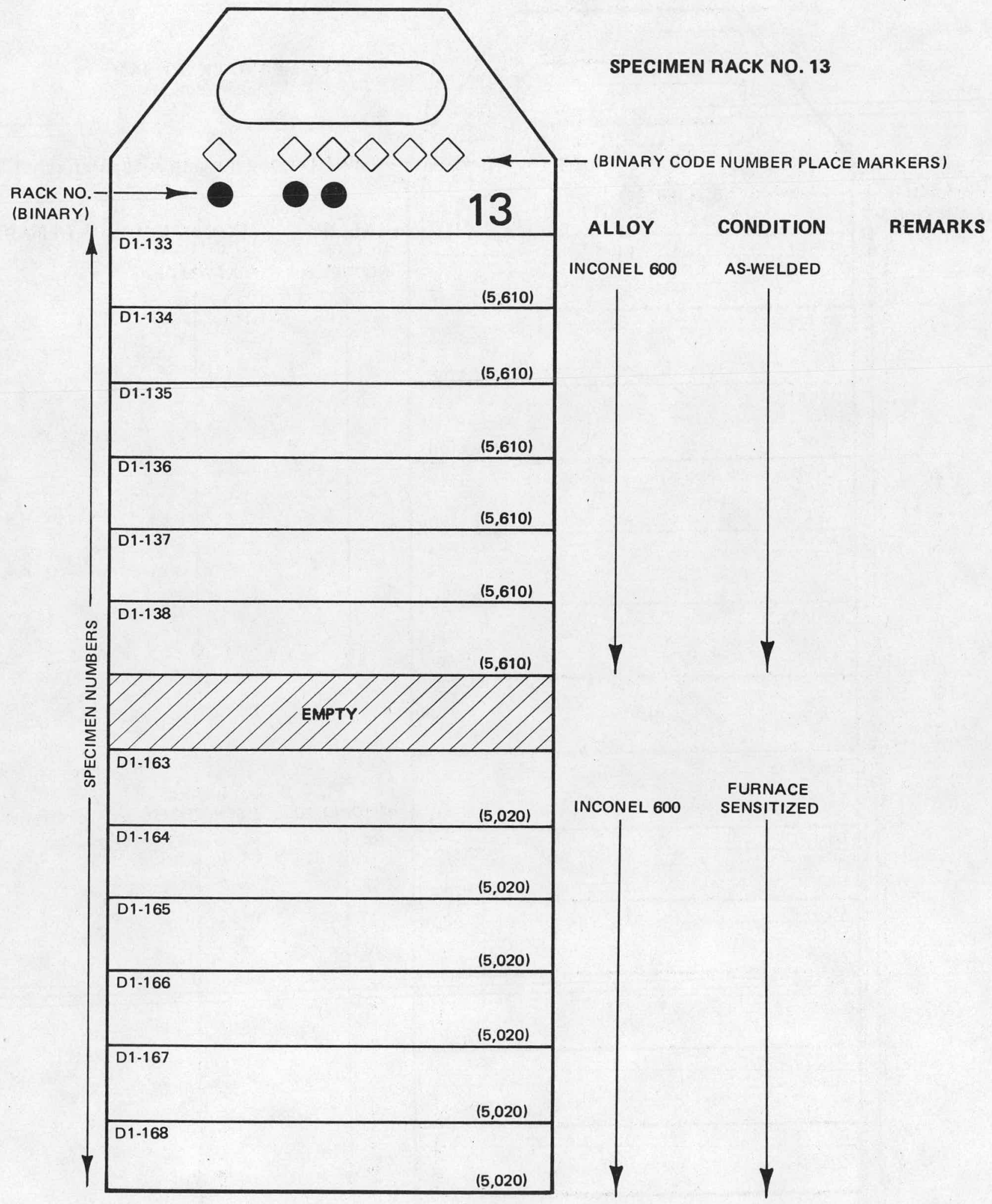




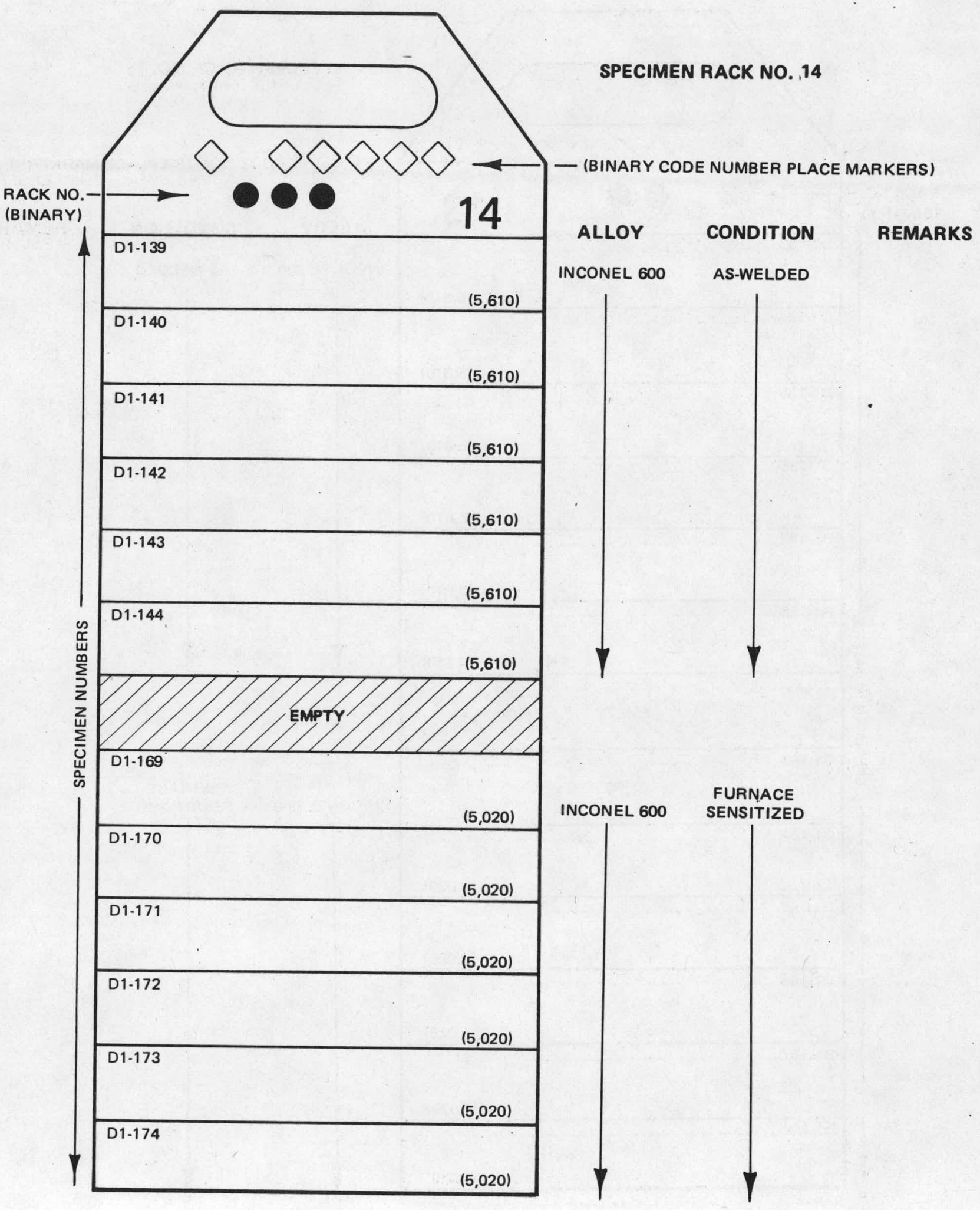




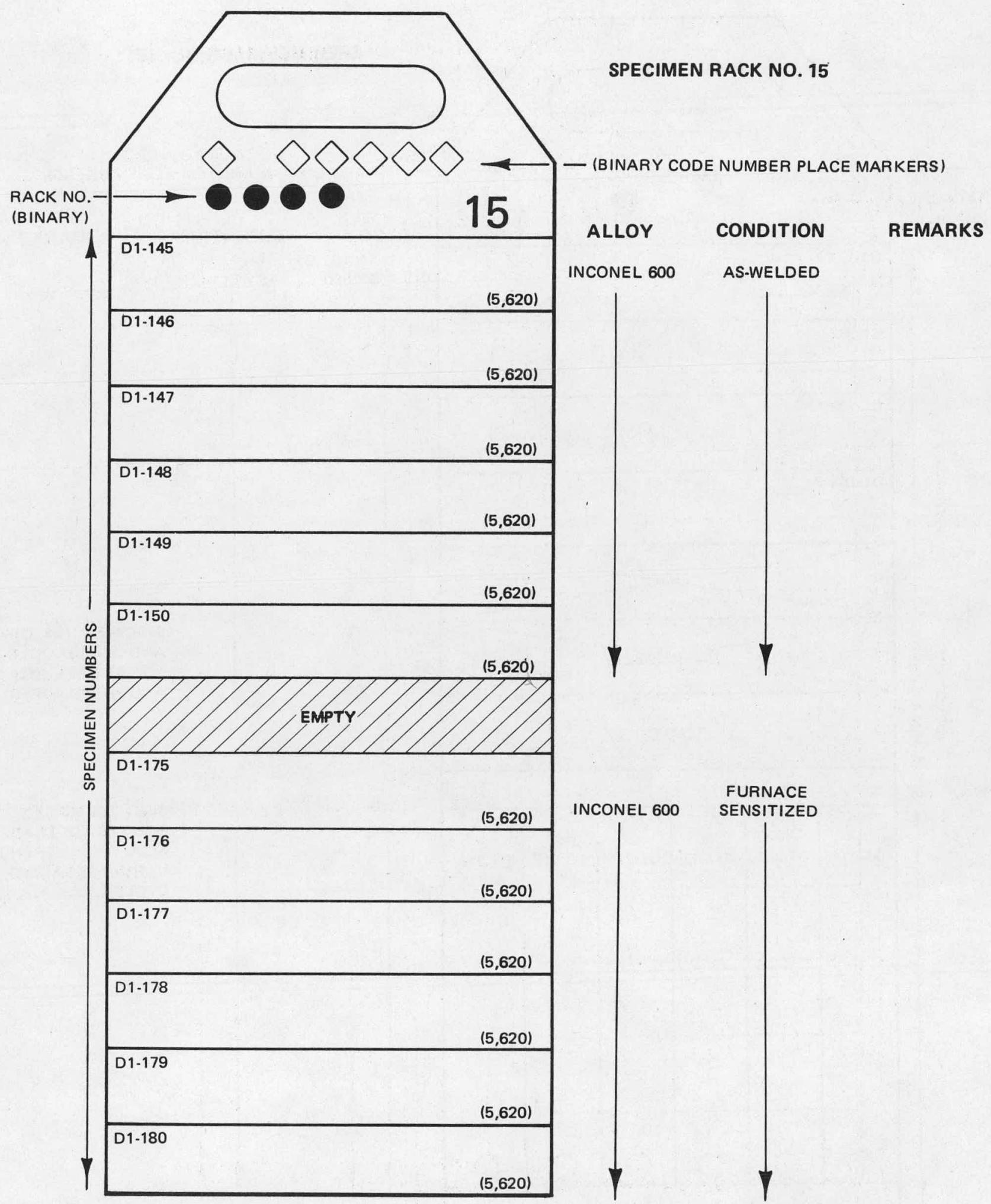




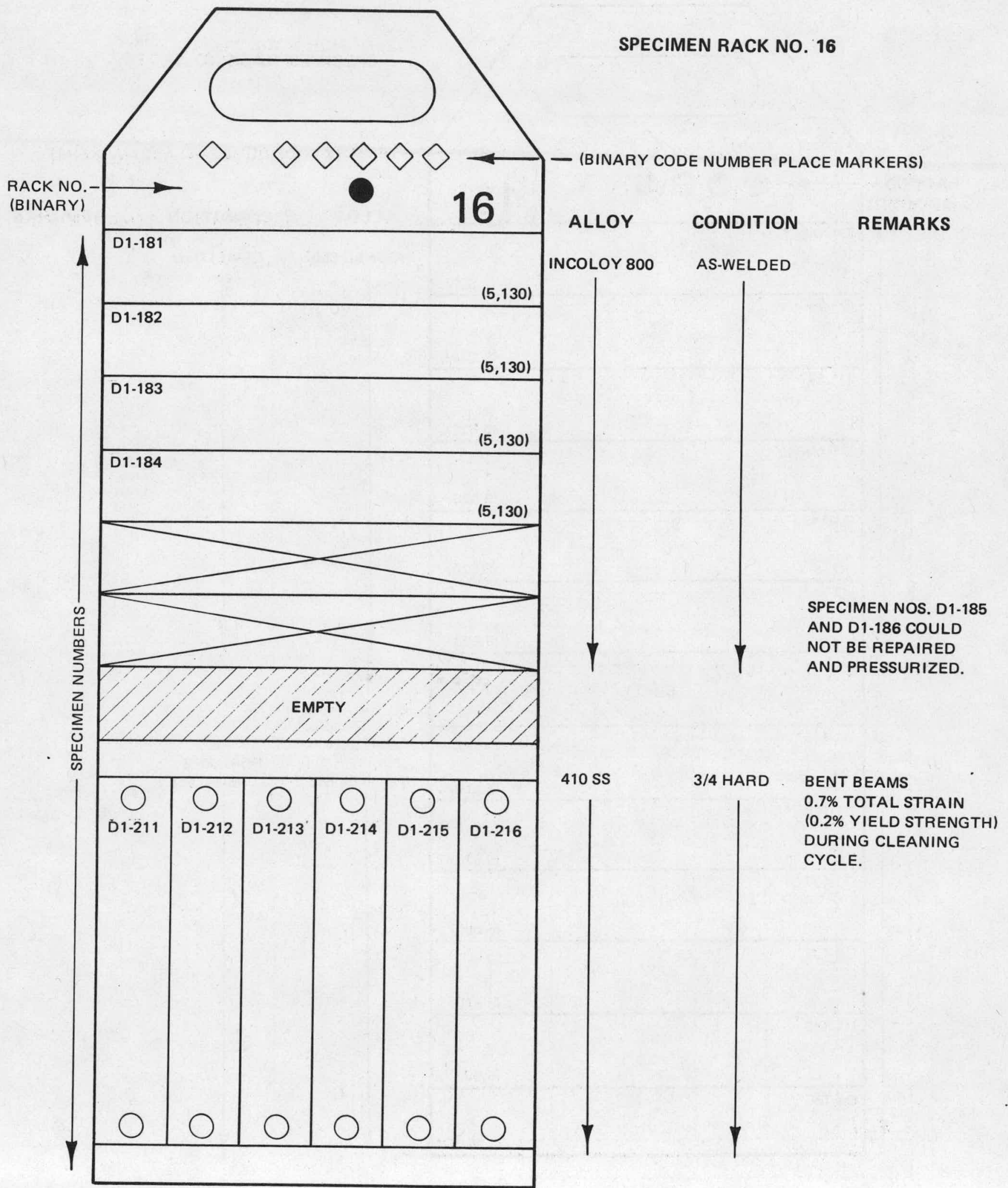




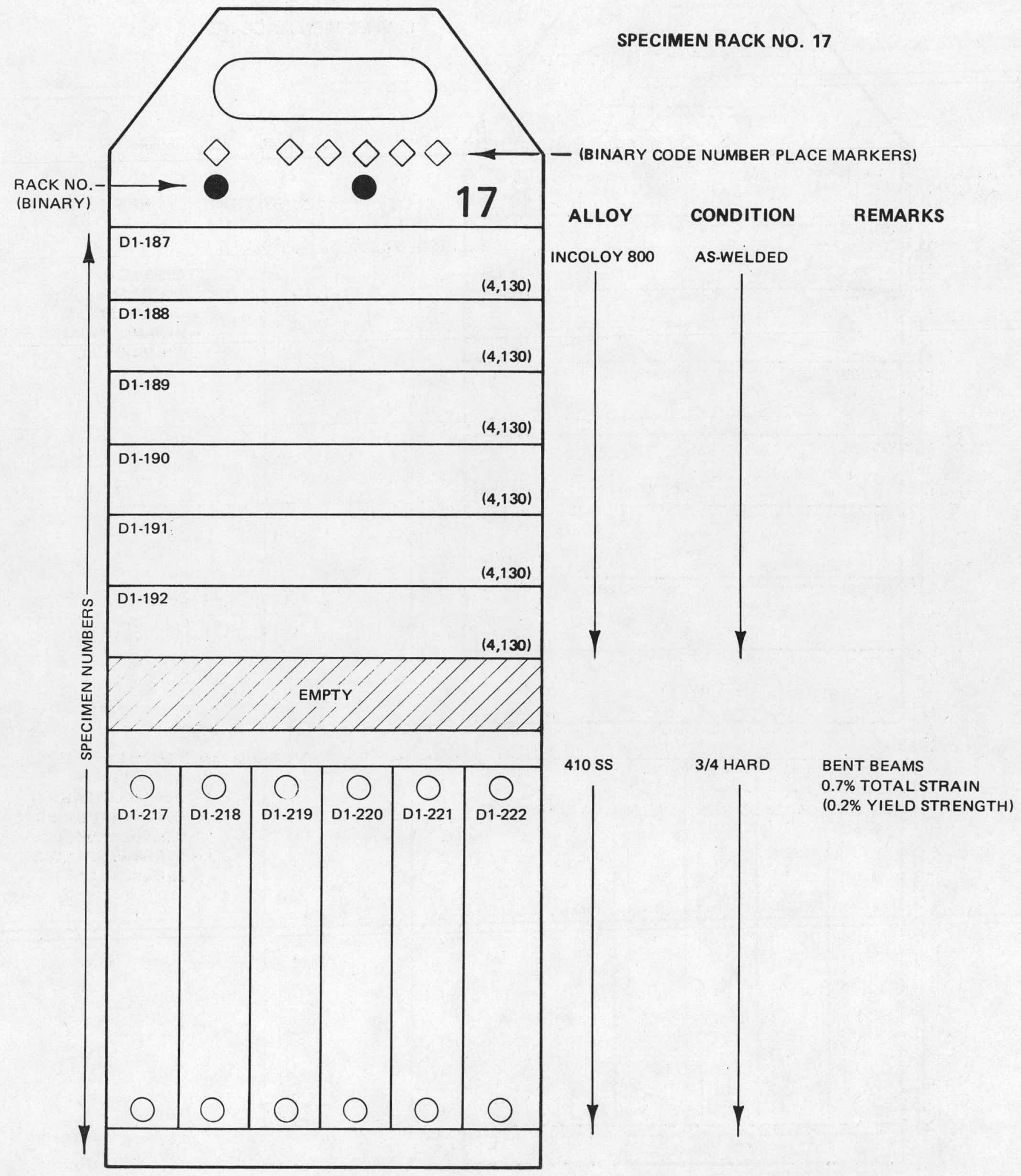




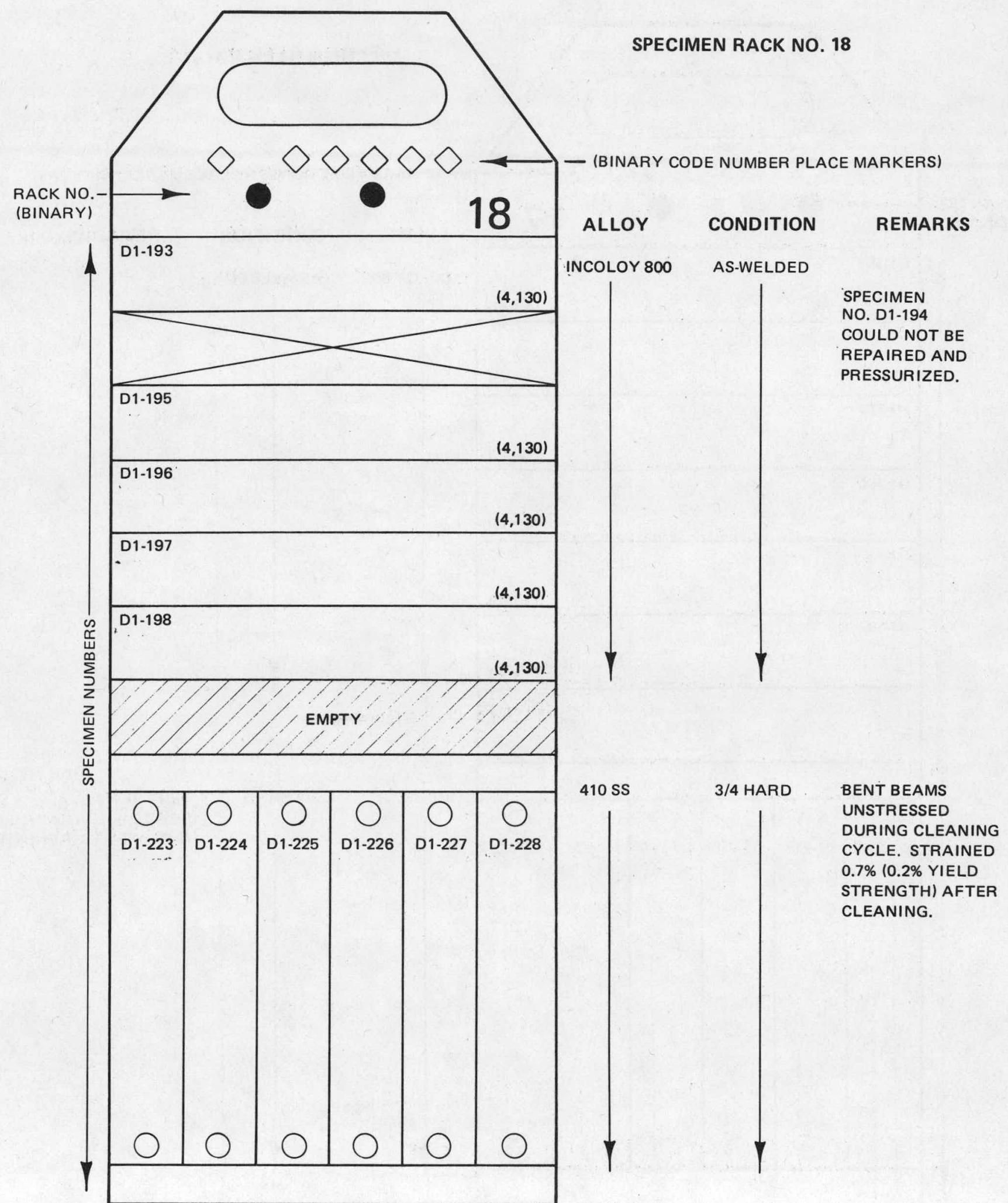




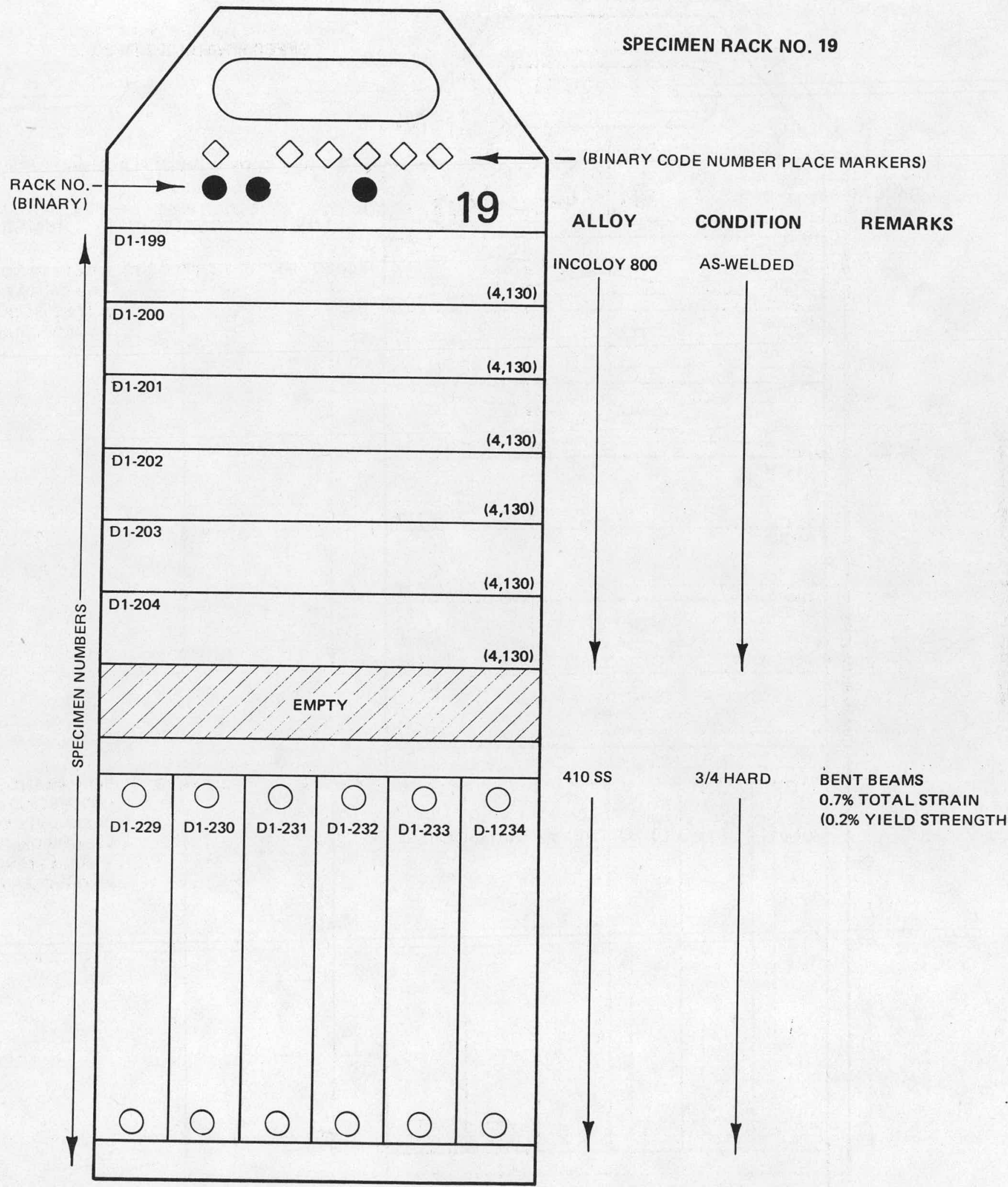




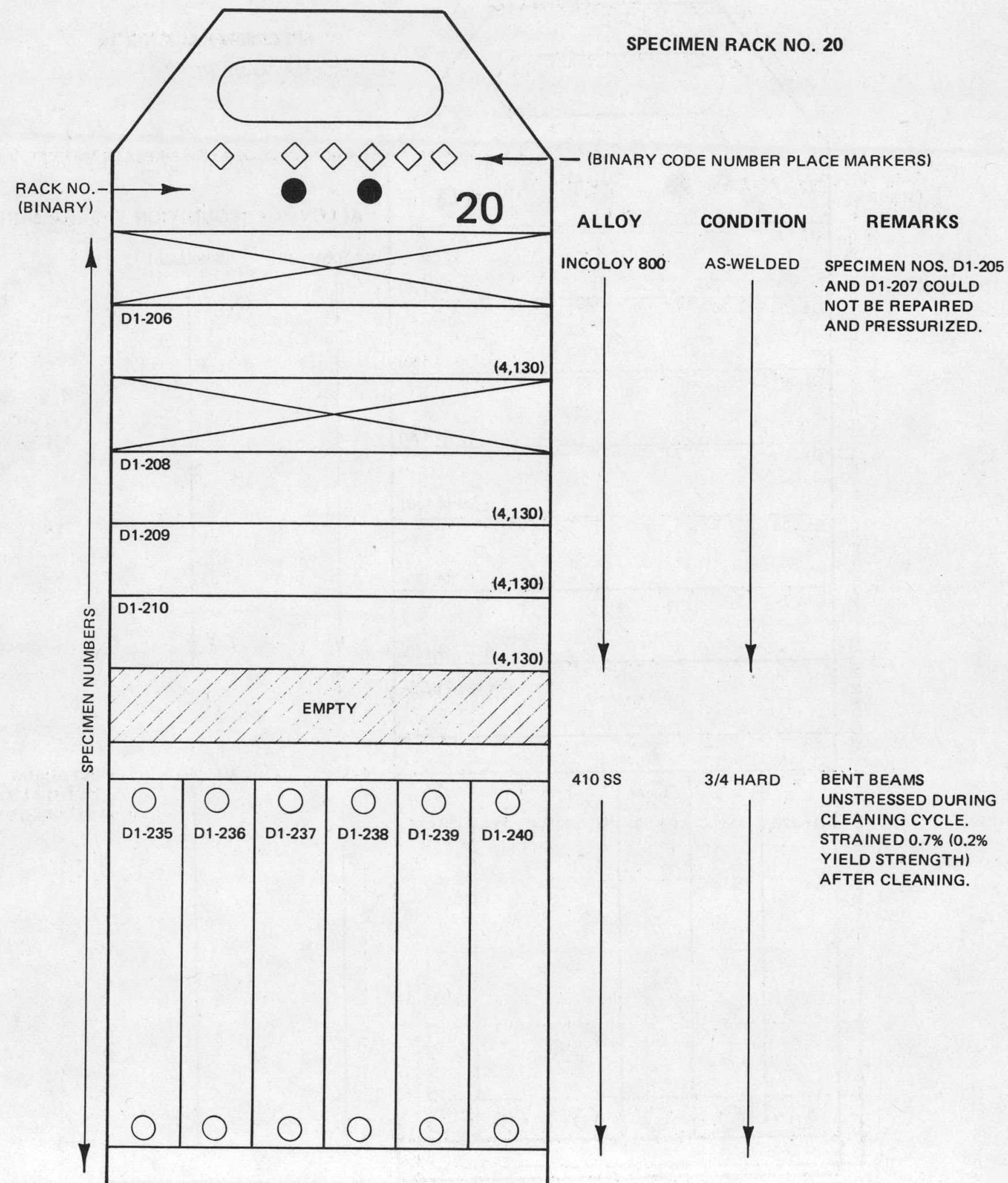




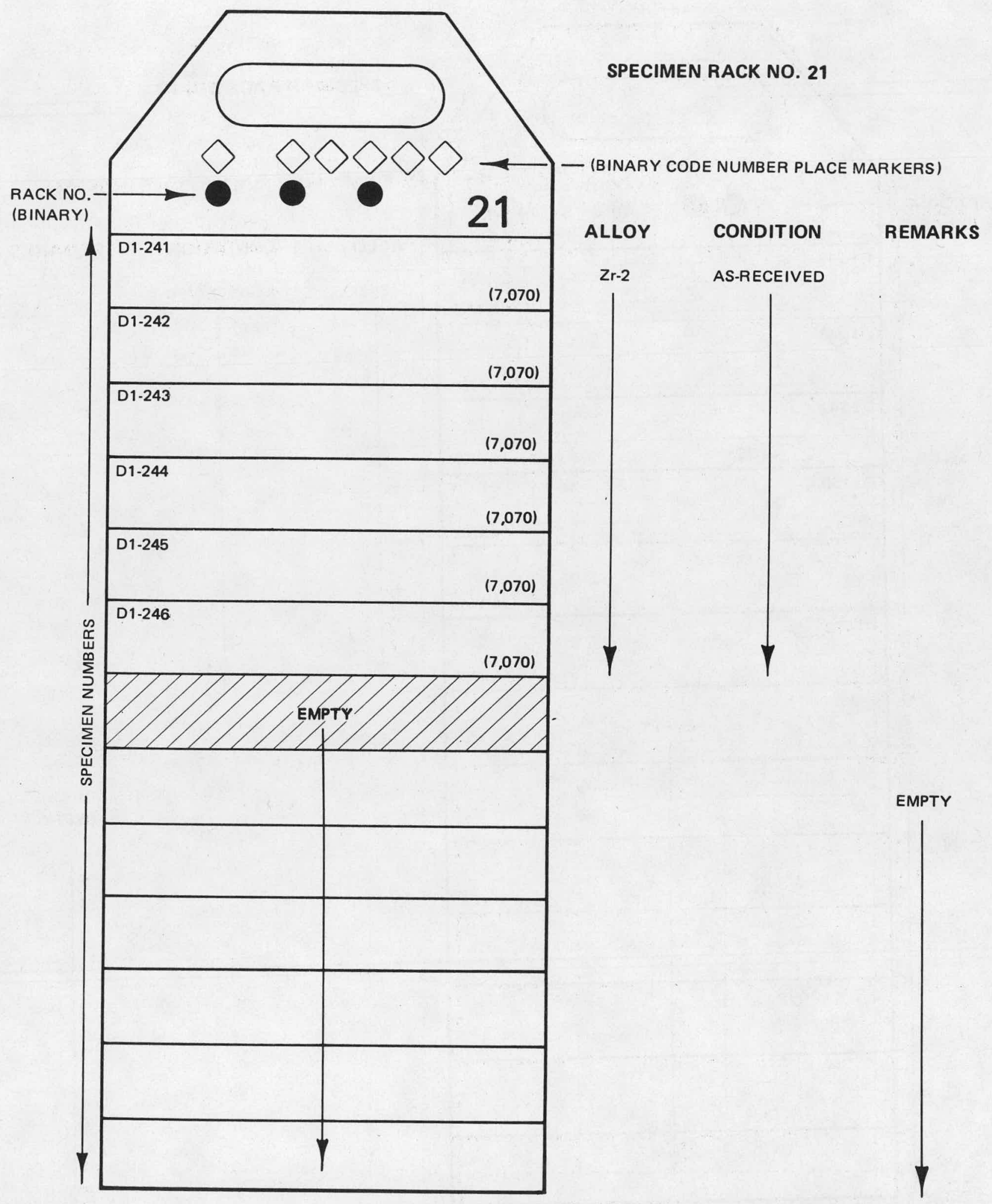




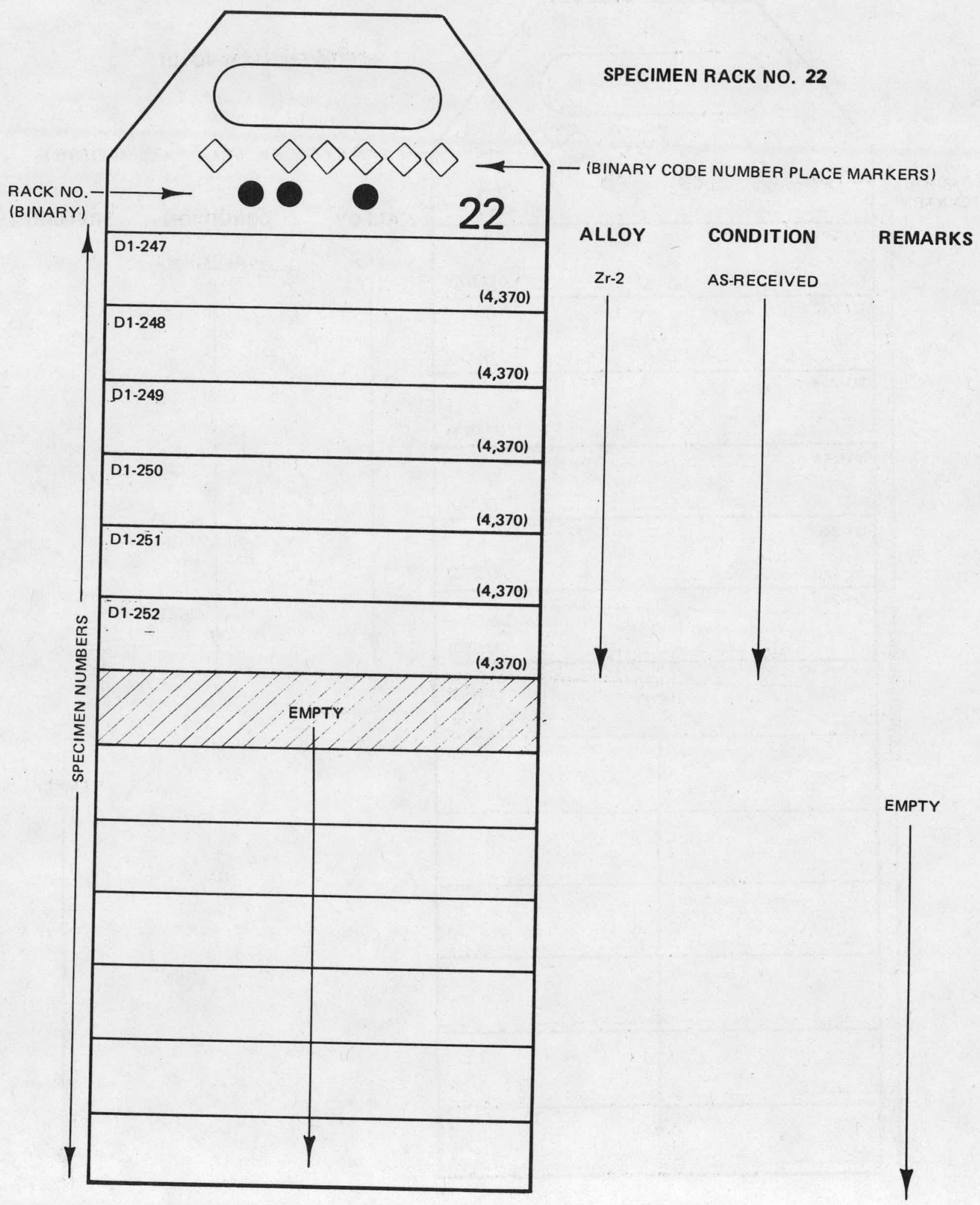




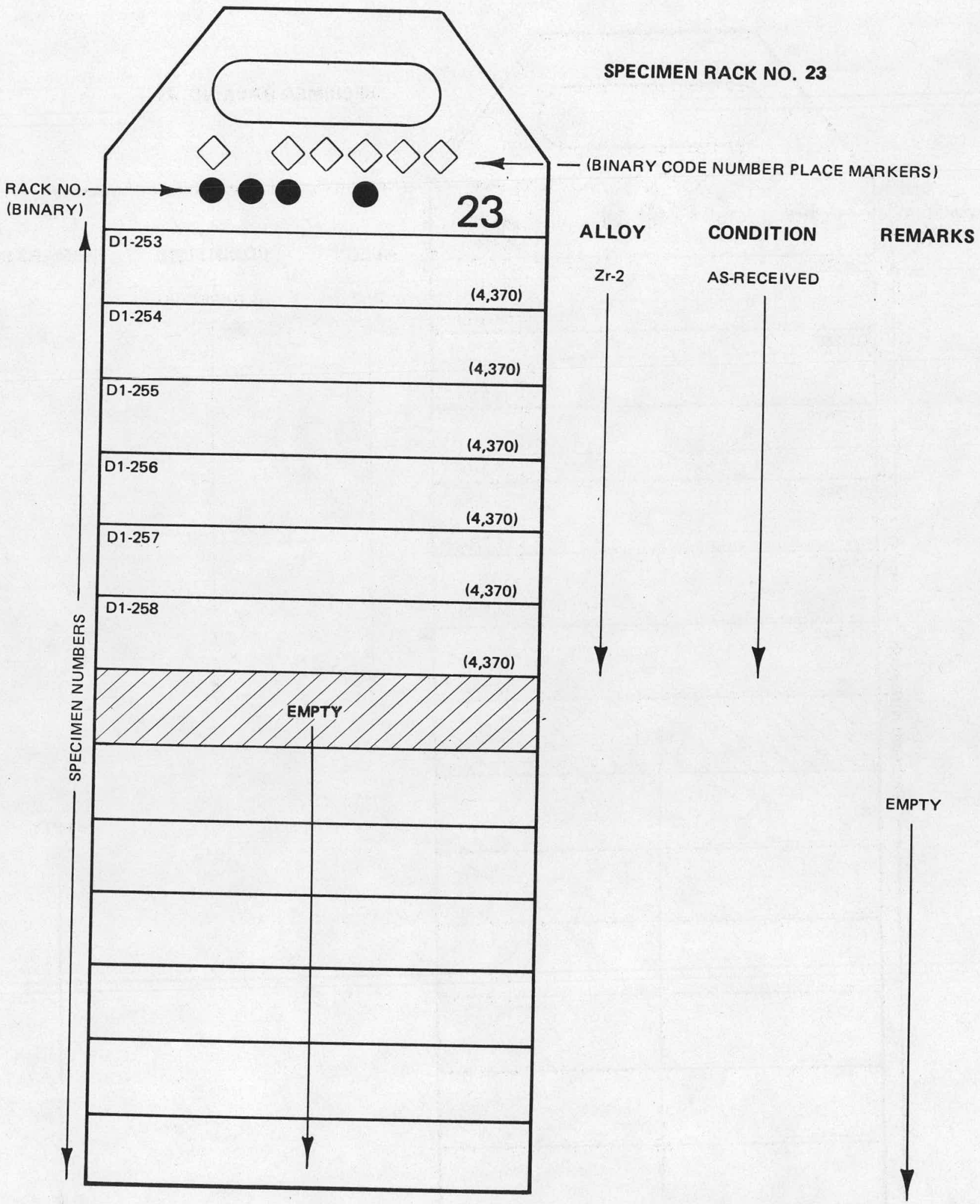




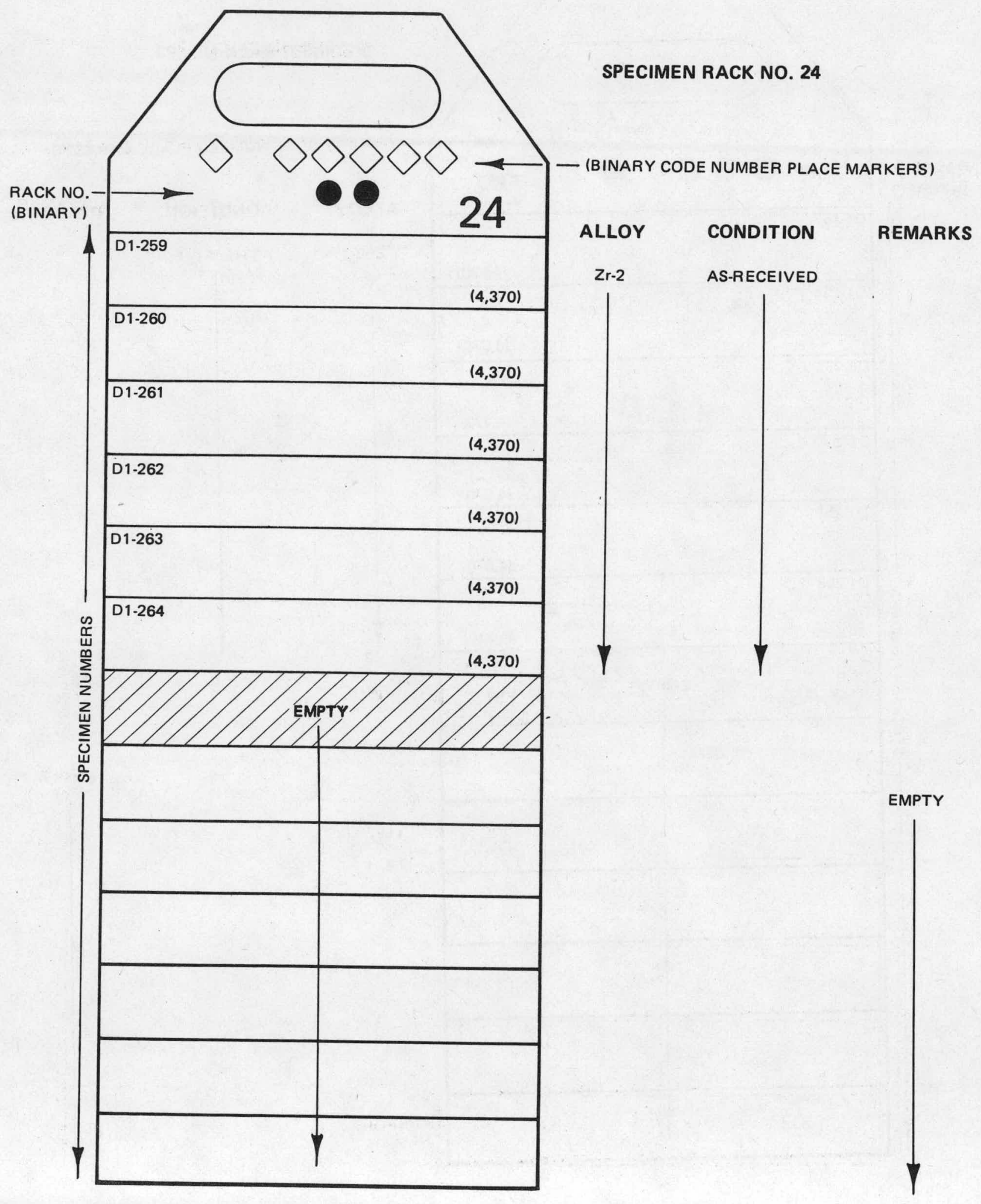




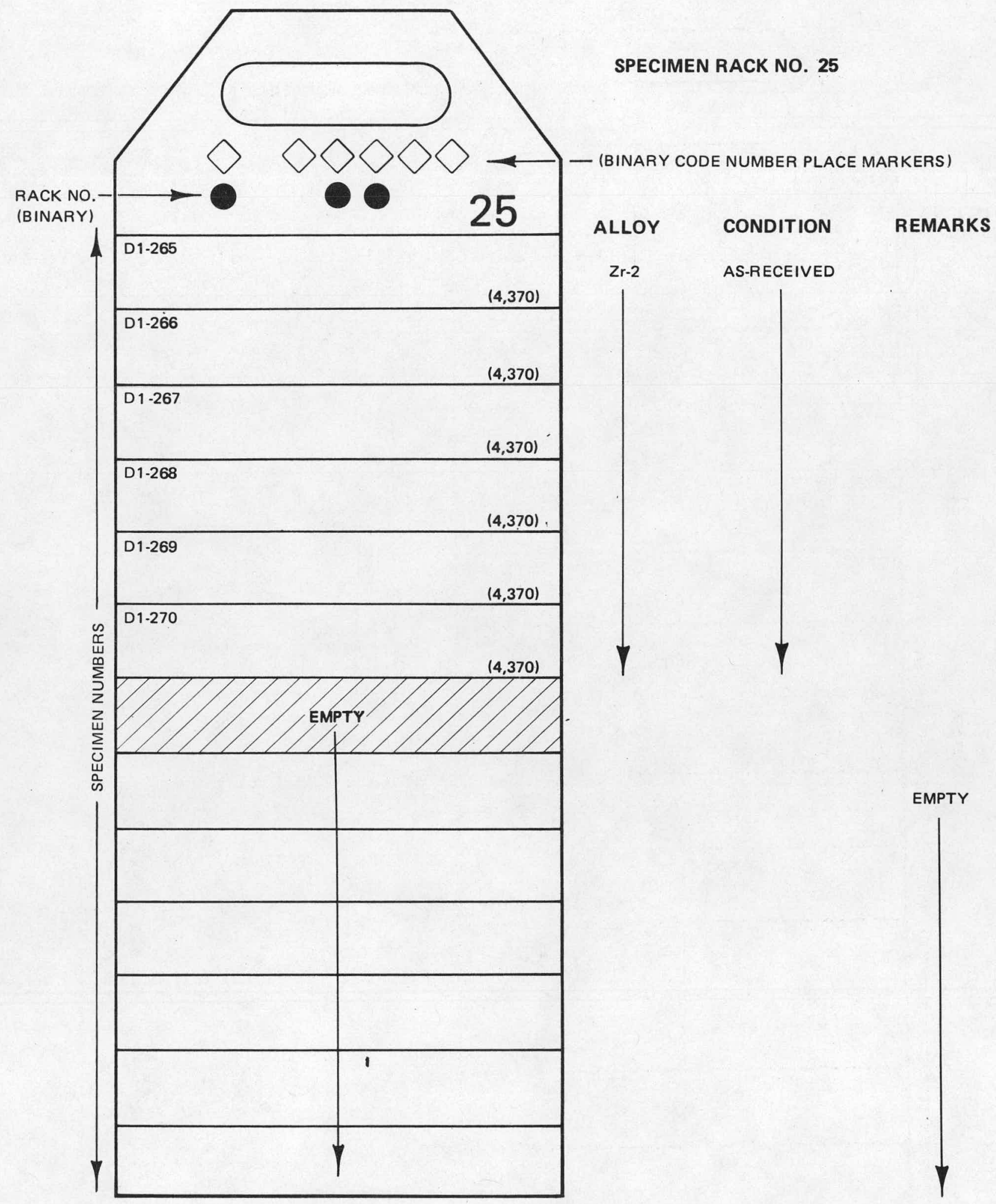

